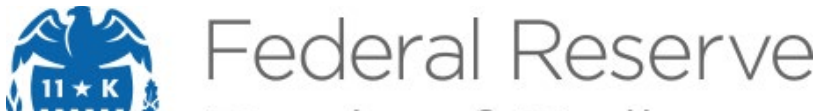 Bank of Dallas
}

\section{Haste Makes Waste: Banking Organization Growth and Operational Risk}

W. Scott Frame, Ping McLemore and Atanas Mihov

Working Paper 2023

Research Department

https://doi.org/10.24149/wp2023

Working papers from the Federal Reserve Bank of Dallas are preliminary drafts circulated for professional comment. The views in this paper are those of the authors and do not necessarily reflect the views of the Federal Reserve Bank of Dallas or the Federal Reserve System. Any errors or omissions are the responsibility of the authors. 


\title{
Haste Makes Waste: Banking Organization Growth and Operational Risk ${ }^{*}$
}

\author{
W. Scott Frame ${ }^{\dagger}$, Ping McLemore ${ }^{\ddagger}$ and Atanas Mihov§
}

May 15, 2020

\begin{abstract}
This study shows that banking organization growth is associated with higher operational losses per dollar of total assets and incidence of tail risks. Event studies using M\&A activity and instrumental variable regressions provide consistent evidence. The relationship between banking organization growth and operational risk varies by loss event types and balance sheet categories. We demonstrate that higher growth predicts worse operational risk realizations during the global financial crisis. These findings have implications for bank performance, risk management and supervision in a continually consolidating banking industry.
\end{abstract}

Keywords: Banking organizations; Operational risk; Growth; Mergers \& acquisitions

JEL Classification: G20, G21

We have benefited from discussions with Azamat Abdymomunov, Gara Afonso, Filippo Curti, Patrick de Fontnouvelle, Kathleen Johnson, Marco Migueis, Hema Parekh, Lisa Ryu, Robert Sarama and James Vickery. We thank Cooper Killen for research assistance. All remaining errors are our own. The views expressed in this paper do not necessarily reflect the position of the Federal Reserve Bank of Dallas, the Federal Reserve Bank of Richmond or the Federal Reserve System.

${ }^{\dagger}$ W. Scott Frame, Vice President, Federal Reserve Bank of Dallas, scott.frame@dal.frb.org.

${ }^{\ddagger}$ Ping McLemore, Financial Economist, Federal Reserve Bank of Richmond, ping.mclemore@rich.frb.org.

§Atanas Mihov, Financial Economist, Federal Reserve Bank of Richmond, atanas.mihov@rich.frb.org. 


\section{Introduction}

Recent research suggests that firms that grow faster have subsequently worse financial performance (e.g., Cooper et al. (2008)). In the context of banking, the singular proposition has been that quickly growing institutions underestimate credit risk and make loans that perform unexpectedly poorly (Fahlenbrach et al. (2017)). Our research identifies an important new channel linking higher growth and weak performance - operational risk. We specifically show that banking organizations that grow faster are also significantly more exposed to operational risk.

Operational risk refers to losses resulting from inadequate or failed internal processes, people, and systems or from external events (Basel Committee on Banking Supervision (2006)). This risk is particularly difficult to measure, monitor and manage when compared to other key banking risks such as credit and market risks. Operational risk is a major risk for banking organizations and has attracted significant attention over recent years as heavy operational losses shook U.S. institutions (Abdymomunov et al. (2020), Afonso et al. (2019)). For example, Wells Fargo recently experienced a number of costly operational failures related to aggressive growth tactics, including opening as many as 2.1 million consumer-banking accounts without customers' knowledge as well as engaging in consumer abuses in the mortgage and auto insurance markets. The bank has paid billions of dollars in penalties and settlements as a result of its misconduct. ${ }^{1}$

While banking industry growth has been principally driven by value-increasing motives such as information technology advancements and economies of scale or scope (e.g., Frame and White (2014), Hughes and Mester (2013), Wheelock and Wilson (2012), Feng and

\footnotetext{
${ }^{1}$ See (i) The Wall Street Journal: "How Wells Fargo's High-Pressure Sales Culture Spiraled Out of Control" (E. Glazer, Sep. 16, 2016); and (ii) Federal Reserve System: "Responding to widespread consumer abuses and compliance breakdowns by Wells Fargo, Federal Reserve restricts Wells' growth until firm improves governance and controls. Concurrent with Fed action, Wells to replace three directors by April, one by year end" (Feb. 02, 2018).
} 
Serletis (2010), Kovner et al. (2014)), it may also give rise to significant operational risks. For example, growth may be driven by short-term incentives of bankers who employ risky practices such as mis-selling of financial products (e.g., Rajan (1994)), strain managerial oversight and impede employee focus (e.g., Brickley et al. (2003), Berger et al. (2005)), or be associated with organizational changes such as mergers and acquisitions (M\&As), which expose companies to systems and workforce integration risks. In this study, we empirically examine the association between large U.S. banking organization growth and operational risk, and document the "net effect" of these various channels.

A considerable advantage of our research is the use of detailed supervisory data. This data is reported to the Federal Reserve System by large U.S. bank holding companies (BHCs) for stress testing purposes as directed by the Dodd-Frank Wall Street Reform and Consumer Protection Act. As cautioned by prior research, public sources of data compiled from press accounts can miss many operational loss events, including large ones (De Fontnouvelle et al. (2006), Abdymomunov et al. (2020)). By contrast, the confidential supervisory data we study is not afflicted by such setbacks and is very rich and comprehensive. While the data is limited to the 38 largest U.S. BHCs, these institutions account for the majority (currently more than $85 \%$ ) of banking industry assets.

Our results can be summarized as follows. First, we document a positive and statistically significant association between operational risk and banking organization growth. A one standard deviation increase in asset growth is associated with a $\$ 57.12$ increase in quarterly operational losses per $\$ 1$ million of BHC assets, a significant $23.8 \%$ increase in relative terms. Event studies using banking mergers and acquisitions and instrumental variables regressions using (peer) institutions' employee growth confirm our results. With respect to operational loss event types, the principal driver of the relation between operational risk and bank growth are failures in obligations to clients, faulty product design, and business practices. In terms of BHC balance sheets, operational risk is related to loan growth and deposit growth. 
We conduct additional exercises in order to better understand the relation between operational losses and banking organization growth. First, we highlight that increases rather than decreases in size is the main driver of increased operational losses. Second, both organic growth and external growth via mergers and acquisitions are positively related to operational risk. Third, growth is positively related to the frequency of tail operational risk events. (Tail risk poses difficulties for banking organization capital planning and management, and is particularly relevant for BHC risk of failure.) Finally, we demonstrate that financial institutions with higher growth before the onset of the global financial crisis incurred worse operational losses during the crisis, evidence consistent with the interpretation that growth amplifies operational vulnerabilities during financial stress periods.

Our study contributes to the literature on operational risk at financial institutions. Jarrow (2008) describes operational risk with a particular focus on economic capital estimation. Cummins et al. (2006) and Gillet et al. (2010) analyze stock market reactions to operational loss announcements at financial institutions. Allen and Bali (2007) study the cyclicality in equity-return-based operational risk measures. Cope and Carrivick (2013) and Abdymomunov et al. (2020) analyze financial industry operational losses over the 2008 crisis period and explicitly link operational risk to the state of the macroeconomic environment. Cope et al. (2012) perform cross-country analysis that relates operational loss severity to a number of regulatory, legal, geographical, and economic development indicators in a cross-country analysis. Chernobai et al. (2011), Wang and Hsu (2013) and Abdymomunov and Mihov (2019) show that corporate governance and risk management quality are related to operational risk outcomes at financial institutions. Chernobai et al. (2020) show that bank holding company expansions into non-banking activities result in more operational risk.

By contrast, our study shows that faster growing banking organizations incur more operational losses per dollar of total assets. These higher losses are sourced to growth in traditional banking activities such as lending and deposit taking and are predominantly 
related to failures in obligations to clients, faulty product design, and business practices. Importantly, growth-induced operational risks might have financial stability implications as they manifest through more frequent high-severity tail events. Further, growth during a benign environment seems to predict adverse operational risk outcomes during financial and economic stress as highlighted by experiences during the global financial crisis.

Our paper also contributes to the academic discourse exploring the effects of firm growth on financial performance. Fahlenbrach et al. (2017) show that faster growing banking organizations under-perform their peers and argue this occurs through a channel of incorrectly priced credit risk. ${ }^{2}$ More broadly, the same phenomenon has been observed also among nonfinancial firms (e.g., Cooper et al. (2008), Watanabe et al. (2013), Hou et al. (2014), Polk and Sapienza (2008)), where a main proposition has been the diminishing marginal returns of capital expenditures. Our findings are distinct but relevant to these studies. Our analyses do not concern investment in production in the conventional sense or credit risk at financial organizations. Rather, our evidence suggests operational risk might be a novel channel for the under-performance of quickly growing banking organizations, and more broadly, other firms. The staggering size of operational losses, as well as the challenges around measurement and monitoring of operational risk both within organizations and by outside investors, suggest this channel might be indeed important. ${ }^{3}$

A distinctive feature of operational risk is its potential for devastating consequences to financial institutions, ranging from large monetary losses and shattered reputations to threatening financial stability (Basel Committee on Banking Supervision (2001), Chernobai et al. (2020)). The significance of operational risk has been recognized by international regulators.

\footnotetext{
${ }^{2}$ Aggregate evidence is consistent - bank credit expansion predicts increased bank equity crash risk and also predicts lower mean bank equity returns (Baron and Xiong (2017)).

${ }^{3}$ Our findings that operational loss increase subsequent to mergers and acquisitions contribute to the literature on long-term returns to M\&A activity. While we are agnostic on whether long-term abnormal returns are positive or negative (see Betton et al. (2008) for an overview), our findings highlight a plausible channel for value destruction - operational risk - that lowers company returns following M\&As (e.g., Roll (1986), Rau and Vermaelen (1998)).
} 
The Basel Capital Accords (Basel II and III) of 2004 and 2009 explicitly separate operational risk from credit and market risks and lay out a set of specific regulatory standards for banking organizations. Better understanding operational risk sources at financial institutions, enhancing governance frameworks to mitigate operational risks, and ensuring institutions' operational resiliency have all been significant focuses of global banking supervision.

The results of our analysis are thus also relevant for supervisory policy. The U.S. banking industry has experienced substantial growth over the past few decades, especially at the very largest institutions (Adams and Driscoll (2018)). Our findings suggest that banking organization growth is a relevant dimension for U.S. BHCs' risk outcomes and should be considered when assessing their operational risk profiles. Specifically, increased supervisory attention to faster growing institutions might be warranted. Separately, our findings also highlight the increase of operational risks around significant organizational changes, such as merger and acquisition activity, and suggest banking organizations might benefit from tightening internal processes and controls around these events. Our findings are topical given the continued consolidation even among the largest U.S. banking organizations. ${ }^{4}$

The rest of this paper is organized as follows. Section 2 describes our data, the construction of variables and descriptive statistics. Section 3 presents our main empirical results. Section 4 checks for robustness. Section 5 discusses the potential channels for our findings. Finally, Section 6 concludes.

\footnotetext{
${ }^{4}$ For example, U.S. regulators approved in 2019 a mega-merger between BB\&T and SunTrust Banks that created the sixth largest institutions in the nation with almost $\$ 450$ billion in assets. See The Wall Street Journal: "Fed Approves BB\&T, SunTrust Banks Merger" (A. Prang, Nov. 19, 2019).
} 


\section{Data Sample and Variable Definitions}

\subsection{Operational Loss Data}

This study uses supervisory data of operational losses submitted by large U.S. bank holding companies pursuant to the Dodd-Frank Wall Street Reform and Consumer Protection Act. The Federal Reserve System collects such data for stress testing purposes under the Comprehensive Capital Analysis and Review (CCAR) program. The data follows FR Y14Q reporting requirements (current as of December 2018) and is provided by 35 financial institutions with consolidated assets of $\$ 100$ billion or more. We supplement this data with data for another three institutions (Comerica, CIT Group and Zions Bancorporation) with consolidated assets in the range of $\$ 50$-100 billion that participated in the 2017 Dodd-Frank Act Stress Test (DFAST) but no longer do so subsequent to the Economic Growth, Regulatory Relief, and Consumer Protection Act of 2018. ${ }^{5}$ Although our operational loss data comes from a relatively small number of institutions, they account for the majority of U.S. banking industry assets (85.9\% as of 2018:Q4). The data is highly granular and provides information such as loss amounts, loss classifications, and loss descriptions.

Banking organizations subject to the regulation have different thresholds for collecting individual operational losses. To mitigate the impact of firm heterogeneity in collection thresholds on our results, we follow prior research (e.g., Abdymomunov et al. (2020)) and discard operational losses below $\$ 20,000$, the highest threshold across reporting institutions. The final sample contains 376,443 individual loss events from a total of 38 large BHCs over the period [2001:Q1-2018:Q4]. Our data is substantially richer than counterparts offered by private vendors. For instance, Chernobai et al. (2011) use a sample with 2,426 loss events

\footnotetext{
${ }^{5}$ More information about FR Y-14Q reporting requirements, instructions and forms can be found at: http://www.federalreserve.gov/apps/reportforms/. Subsequent to the Economic Growth, Regulatory Relief, and Consumer Protection Act of 2018, financial institutions with under $\$ 100$ billion in total assets are no longer required to file the FR Y-14Q reports effective May 2018. Comerica, CIT Group and Zions Bancorporation drop out from our sample after 2018:Q1.
} 
from Algo FIRST and Hess (2011) uses around 7,300 loss events from SAS OpRisk Global Data. Furthermore, as discussed in de Fontnouvelle et al. (2006), operational risk data sets based on publicly available information are likely to omit substantial losses otherwise contained in the supervisory data that we use.

To examine the relationship between operational risk and BHC asset growth, our analysis aggregates loss data at the bank-quarter level. We use the quarter of the date when an operational loss event occurred or began for aggregation purposes. In particular, we build an unbalanced panel of 1,644 bank-quarter observations over the period [2001:Q1-2018:Q4] in accordance with individual BHC data availability.

\subsection{Operational Risk Variables}

Table 1 presents variable definitions. Our main measure of operational risk is the total dollar value of operational losses that occur at a $\mathrm{BHC}$ in a given quarter. We follow Abdymomunov and Mihov (2019) and other studies in the literature on bank risk and performance (e.g., James (1991), Ahmed et al. (1999), Ellul and Yerramilli (2013)), and scale losses by BHC asset size. To avoid a potential mechanical relation between operational losses and institution size (e.g., an asset impairment channel of operational risk), we use lagged total assets. Notably, our results are also robust to using contemporaneous measurements of losses and assets. For presentation purposes, we multiply the loss-to-assets ratio by 1,000 and label it $L t A$. In some of our regression specifications, we also use log-transformed dollar losses, $\operatorname{Ln}($ Loss) that occur at an institution in a given quarter.

[Insert Table 1 about here]

Table 2 presents descriptive statistics. On average, the BHCs in our sample lose $\$ 182$ million or the equivalent of $0.024 \%$ of their assets per quarter to operational risk. Further, the standard deviations of both dollar losses ( $\$ 1.4$ billion) and asset-scaled operational losses 
$(0.088 \%)$ are high relative to the means, indicating substantial time-series and cross-sectional variation of operational losses.

[Insert Table 2 about here]

A well-known property of operational losses is the extremely heavy tails of the empirical loss distributions (Chernobai and Rachev (2006), Jobst (2007)). Indeed, only a few "catastrophic" operational risk events account for a large proportion of the total dollar losses in our sample. Thus, while we focus on quarterly operational losses at BHCs, we also analyze tail operational risk. For our analysis, we use three measures of tail risk frequency - N Tail 90, $N$ Tail 95, and N Tail 99 - constructed as follows. We start with the 376,443 individual loss events in our sample and scale dollar loss amounts by BHC total assets. We calculate the $90^{\text {th }}, 95^{\text {th }}$ and $99^{\text {th }}$ quantiles of the resulting empirical distribution and categorize all loss events with severities above the respective quantiles as "tail losses." We then "collapse" the sample of losses at the BHC-quarter level by counting the number of tail events that occur at a given institution during a given quarter for each tail threshold definition. We label the variables $N$ Tail 90, $N$ Tail 95 and $N$ Tail 99, respectively.

\subsection{Measure of BHC Growth and Control Variables}

We use the year-over-year growth in BHC total consolidated assets, Asset Growth, as our main measure of banking organization growth. Specifically, the variable is defined as follows:

$$
\text { Asset }_{\text {Growt }} h_{i, t}=\frac{\text { Asset }_{i, t}-\text { Asset }_{i, t-4}}{\text { Asset }_{i, t-4}}
$$

where $i$ indexes BHCs and $t$ indexes time (calendar quarters). In later sections, we decompose Asset Growth into major asset and other balance sheet categories and show the robustness of our results to using different time horizons to measure growth. 
Our multivariate regression analysis also includes a number of control variables. Curti et al. (2019) demonstrate that among large U.S. bank holding companies, the largest ones are most exposed to operational risk. We thus include the natural log transformation of BHC total consolidated assets ( $\operatorname{Ln}($ Assets $))$ to control for size. We include the interest to noninterest income ratio (II-to-NII) to account for exposure to business activities. Brunnermeier et al. (2020) document that traditional banks (deposit receiving and lending) have different risk profiles from financial institutions with higher non-interest income (non-core activities such as trading and investment banking). For similar reasons, we also explicitly control for the proportion of assets funded trough deposits (Deposits-to-Assets) and the proportion of lending relative to total assets (Loans-to-Assets).

We control for BHC profitability as measured by the return on equity $(R O E)$, which we define as the ratio of net income to book value of equity. On the one hand, higher profitability may allow the allocation of more resources to risk management. On the other hand, senior management can turn a blind eye to internal control failures when firms are profitable and financially unconstrained (Jin and Myers (2006)). Because operational risk is closely related to credit risk as argued by Chernobai et al. (2011), we also control for BHCs' loan charge-off rates (Loan Losses). To further control for BHC risk we include BHC tier 1 risk-based capital (Tier 1 Capital) and the log-absolute difference between assets and liabilities that reprice or mature within a year (Maturity Gap).

Finally, we also control for the state of the macroeconomic environment. As Abdymomunov et al. (2020) document, BHCs incur more operational losses in adverse conditions. We thus include the year-over-year U.S. real GDP growth rate (GDP Growth). In addition, we include an indicator variable for the financial crisis period, Financial Crisis 200\%-09, defined as 1 over the period [2007:Q4-2009:Q2], and 0 otherwise. This definition reflects the official business cycle contraction period as published by the National Bureau of Economic 
Research (NBER), but our results are also robust to alternative crisis period definitions. ${ }^{6}$

\subsection{Correlations}

We start with a simple correlation analysis. Table 2, Panel B reports correlation coefficients between Asset Growth and operational risk variables. Most notably, the correlations between Asset Growth and LtA, and Asset Growth and Ln(Loss), are 11\% and 12\%, respectively. Faster growing banking organizations not only have more operational losses in dollar terms, but also incur more operational risk per dollar of assets. The correlation coefficients are significant at the $1 \%$ level. Figure 1, which presents a bar chart of the average LtA for BHCs sorted in quintiles based on total asset growth: "Low", "2", "3", "4" and "High", highlights the same point, the positive relation between Asset Growth and LtA, visually.

[Insert Figure 1 about here]

Table 2 additionally indicates strong positive correlations between Asset Growth and our measures of tail risk ( $N$ Tail 90, $N$ Tail 95 and $N$ Tail 99). In all cases, the correlation coefficients are again significant at the $1 \%$ level.

\section{$3 \quad$ Regression Results}

\subsection{Operational Losses}

To further examine whether faster organizational growth is associated with more operational risk, we estimate the following specification using Ordinary Least Squares (OLS):

$$
L t A_{i, t}=\beta_{i}+\beta_{1} \text { Asset Growth } \text { Grt-1 }_{i}+\beta_{2} \text { Controls }_{i, t-1}+\epsilon_{i, t}
$$

\footnotetext{
${ }^{6}$ More information on U.S. business cycle expansions and contractions can be found at: http://www . nber.org/cycles.html.
} 
where $i$ indexes BHCs and $t$ indexes time periods (quarters). $L t A_{i, t}$ measures operational losses as a proportion of (lagged) total assets that occur at BHC $i$ during quarter t. Asset Growth $h_{i, t-1}$ measures BHC total assets growth. Controls $s_{i, t-1}$ represents our previously discussed vector of control variables. All explanatory variables are lagged one period. We cluster standard errors at the BHC and quarter levels to account for within-bank and within-quarter correlation of the error terms, and include BHC fixed effects $\left(\beta_{i}\right)$ to absorb cross-sectional differences in operational losses due to time-invariant and persistent factors (e.g., risk management quality, business models, corporate cultures, etc.). To conserve statistical power given our relatively small sample size, in lieu of potentially too granular time fixed effects, we use year-over-year GDP growth and an indicator variable for the 2008-09 financial crisis period to eliminate the effects of economic conditions that are common across banks (Section 4 shows our results are also robust to using quarter fixed effects instead). Table 3, Panel A presents the results.

[Insert Table 3 about here]

The results in Column (1) suggest that banking organizations, which have higher asset growth experience more operational losses per dollar of assets. The coefficient estimate of Asset Growth is positive and statistically significant at the $1 \%$ level. A one standard deviation increase in Asset Growth is associated with a $\$ 57.12$ increase in quarterly operational losses per $\$ 1$ million of $\mathrm{BHC}$ assets, which is a $23.8 \%(=(0.340 \times 0.168) / 0.240)$ increase in LtA relative to its mean. In Column (2), using a different operational loss measure as the dependent variable, Ln(Loss) or the log-transformed operational dollar losses that occur at BHC $i$ during quarter $t$, we find consistent evidence: a 1 percentage point increase in asset growth is associated with a $0.34 \%$ increase in operational losses.

We find that the estimated coefficients on control variables are most often insignificant 
and not robust across different specifications. ${ }^{7}$ An exception to this observation is the coefficient estimate on Financial Crisis 2007-09, which is always positive and significant at the $10 \%$ level. This result suggests that the BHCs in our sample experienced elevated levels of operational losses during the global financial crisis (Abdymomunov et al. (2020)). We do not observe, however, amplified effects of growth during the financial crisis. In unreported tests, we find that an interaction term between Asset Growth and Financial Crisis 2007-09 is negative and insignificant. We further discuss the relation between growth prior to the financial crisis and operational risk realizations during the financial crisis in Section 3.5.

A natural question that arises is whether these results are driven by growing institutions (positive growth) that have higher operational losses or alternatively institutions that are shedding assets (negative growth) that also experience lower operational losses. These two alternative mechanisms have important implications for the interpretation of results. While positive growth associated with more operational risk is consistent with channels such as short-term incentives to book business through risky practices, lapses of managerial oversight and employee attention due to insufficient staffing, and/or organizational changes such as M\&A activity, negative growth associated with a reduction in operational risk might be more reflective of strategic organizational motives driven by BHCs decreasing operationally risk asset holdings to curtail losses.

To answer this question, we decompose Asset Growth into two variables that account for negative vis-a-vis positive growth: Asset Growth (Negative) and Asset Growth (Positive). Specifically, Asset Growth (Negative) equals Asset Growth for observations where Asset Growth < 0, 0 otherwise. In contrast, Asset Growth (Positive) equals Asset Growth for observations where Asset Growth $>=0,0$ otherwise. We then proceed to test the re-

\footnotetext{
${ }^{7}$ We note that in contrast to Curti et al. (2019) who document a positive relationship between operational losses and BHC size, our results document a mostly negative relationship, albeit not robust across all specifications. This difference is driven by the use of BHC fixed effects in our specifications, which zero in on within-BHC variation in the data to identify regression coefficients.
} 
lation of these two variables with our main operational loss measure $L t A$. The results in Column (3) show that the significantly positive relation between operational losses and asset growth is exclusively driven by expansions in banking organization size.

Banks can grow in size in two primary ways: through mergers and acquisitions or through organic growth. Thus, a natural next question is which "mode" is driving the positive association between BHC growth and operational losses. To operationalize our tests, we build a list of mergers and acquisitions with information from the National Information Center (NIC) on banking organization mergers and entity relationships. The data allow us to construct a mapping of a merged or acquired entity to a final "surviving" parent institution. $^{8}$ Each merged entity is required to have a valid RSSD identifier at the time of the merger and file regulatory reports (e.g., FR Y-9C, OTS 1313 Thrift Financial Report, or FFIEC 031/041). The intersection of our main sample and the list of mergers identified from NIC yields a total of 159 mergers.

We then decompose Asset Growth into growth via mergers and acquisitions, Asset Growth (MEA), and organic growth, Asset Growth (Organic). The variables are defined as follows:

$$
\begin{aligned}
& \text { Asset Growth }(M \& A)_{i, t}=\frac{A s s e t s(M \& A)_{i, t}}{\text { Assets }_{i, t-4}} \\
& \text { Asset Growth }(\text { Organic })_{i, t}=\frac{\text { Asset }_{i, t}-\text { Assets }(M \& A)_{i, t}-\text { Assets }_{i, t-4}}{\text { Asset }_{i, t-4}}
\end{aligned}
$$

where Assets $(M \& A)_{i, t}$ is the sum of acquired banks' assets by bank $i$ over the period $[t-3, t]$ and Assets $_{i, t}$ is bank $i$ 's total assets in quarter $t$.

Table 3, Column (4) presents regression results relating BHC operational losses and

\footnotetext{
${ }^{8}$ To do this, we trace chains of mergers through the NIC data to the final surviving entities in each chain, and then find these surviving entities' most recent high holders using the relationships data. We continue this process until all transactions and relationships have been accounted for and we have a mapping between each RSSD and a final surviving high holder as of the end quarter of the data. In addition, the ultimate parents of several banks in the sample are foreign institutions. This means that a non-US firm is listed as these entities' high holder in the NIC data. In these cases, we replace the ultimate parent with the highest US holding company for all entities that link to this set of foreign institutions through the highest U.S. banks.
} 
M\&A vis-à-vis organic asset growth. Both modes contribute to higher operational losses at banking organizations - the coefficients of Asset Growth-MEGA and Asset Growth-Organic are positive and significant at the $5 \%$ level. The coefficient of Asset Growth-MEA is about 1.5 times larger than that of Asset Growth-Organic, suggesting somewhat more pronounced loss effects associated with growth from mergers and acquisitions.

\subsection{Balance Sheet Categories}

The relation between $\mathrm{BHC}$ operational risk and growth could be driven by a variety of balance sheet categories. We decompose bank assets in several major categories in accordance with reporting form FR Y-9C: Cash (cash and balances due from depository institutions), Securities (securities), Fed Funds Sold Plus (federal funds sold and securities purchased under agreements to resell), Loans (loans and lease financing receivables), Trading Assets (trading assets), and Other Assets (premises and fixed assets, other real estate owned, investments in unconsolidated subsidiaries and associated companies, direct and indirect investments in real estate ventures, intangible assets, and other assets). Figure 2, Panel A presents an aggregate asset composition chart for the BHCs in our sample. ${ }^{9}$ Loans constitutes the largest asset category, accounting for more than $40 \%$ of total assets on average. The remaining categories are relatively evenly sized with Cash, Securities, Fed Funds Sold Plus, Trading Assets and Other Assets accounting for 8.6\%, 13.9\%, 12.7\%, 13.3\% and 10.5\%, respectively.

\section{[Insert Figure 2 about here]}

Similarly we examine the major balance sheet categories used to finance assets: Deposits (deposits), Fed Funds Purchased Plus (federal funds purchased and securities sold under agreements to repurchase), Trading Liabilities (trading liabilities), Other Borrowed Money

\footnotetext{
${ }^{9}$ Items in each category, measured as a proportion of total assets, are first averaged within BHCs and then averaged across BHCs.
} 
(borrowed money including mortgage indebtedness and obligations under capitalized leases), Other Liabilities (subordinated notes and debentures, subordinated notes payable to unconsolidated trusts issuing trust preferred securities, and trust preferred securities issued by consolidated special purpose entities, and other liabilities), Stock \& Surplus (perpetual preferred stock and related surplus, common stock and surplus), and Retained Earnings Plus (retained earnings and other residual equity capital components). Figure 2, Panel B shows the liability and equity capital items as share of total assets. Deposits constitutes the largest category - the firms in our sample fund approximately half of their assets, $48.1 \%$, with deposits. The remaining categories fund the other half: Fed Funds Purchased Plus - 9.3\%, Trading Liabilities - 5.6\%, Other Borrowed Money - 16.1\%, Other Liabilities - 10.6\%, Stock E Surplus $-6.8 \%$ and Retained Earnings Plus $-3.5 \%$.

We next proceed to examine how growth in each of these balance sheet categories is related to bank operational risk. Table 4 presents the results.

[Insert Table 4 about here]

Panel A shows that Loan Growth is the single major driver on the assets side, while Panel B shows that Deposit Growth is the single major driver on the liabilities and equity side. The coefficient of Loan Growth is similar in magnitude to that of Asset Growth in Table 3, while that of Deposit Growth is smaller (about 1.5 times). This suggests somewhat weaker loss effects stemming from deposit growth relative to loan growth. In unreported results, we further examine whether these results are driven by specific loan (e.g., construction and development, residential mortgages, commercial and industrial loans and consumer loans) and deposit (e.g., insured, uninsured, brokered) sub-categories. We find no evidence to that effect. 


\subsection{Operational Loss Event Types}

Operational risk has many different causes. Losses in our sample are categorized into seven event types (consistent with Basel II Accord classifications): Internal Fraud (IF), External Fraud (EF), Employment Practices and Workplace Safety (EPWS), Clients, Products and Business Practices (CPBP), Damage to Physical Assets (DPA), Business Disruption and System Failures (BDSF), and Execution, Delivery and Process Management (EDPM). Table 1, Panel B includes definitions and Figure 3 presents the allocation of losses across the seven event type categories. ${ }^{10}$ The figure suggests that the most significant portion of losses, $74.4 \%$, can be traced to the Clients, Products and Business Practices event type. The second most significant event type is Execution, Delivery and Process Management, which accounts for 15.1\%. Notably, CPBP and EDPM together accounted for close to $90 \%$ of operational losses in our sample. On the other side of the spectrum, Business Disruption and System Failures is the smallest event type, which accounts for only $0.7 \%$ of the losses.

\section{[Insert Figure 3 about here]}

In the previous section, we documented a significant relation between operational losses and $\mathrm{BHC}$ growth after aggregating losses across all seven categories and ignoring the heterogeneity of operational risk in the different groups. In this section, we re-estimate this relation at the individual loss event category level. Specifically, we re-estimate Equation 2 for each loss event type separately. We note that a priori we do not have a clear expectation of which particular sub-categories of operational losses are correlated with BHC growth. Table 5 presents the results.

\section{[Insert Table 5 about here]}

The coefficient signs of Asset Growth are significantly different from zero in only two

\footnotetext{
${ }^{10}$ Losses in each event type, measured as a proportion of total losses, are first averaged within BHCs and then averaged across BHCs.
} 
specifications - for event type EPWS in Column (3) and event type CPBP in Column (4). As reported in Table 1, Panel A, EPWS captures losses from "[a]cts inconsistent with employment, health or safety laws or agreements, from payment of personal injury claims, or from diversity/discrimination events." CPBP captures losses from "[a]n unintentional or negligent failure to meet a professional obligation to specific clients, or from the nature or design of a product." Importantly, while EPWS accounts for a mere $3.1 \%$ of operational losses in our data, CPBP accounts for the majority of $\mathrm{BHC}$ operational risk $-74.4 \%$ of total losses. Also important to note is that the coefficient on Asset Growth is orders of magnitude larger for CPBP relative to EPWS. This finding thus suggests that the strong positive association between operational risk and BHC size is largely driven by one type of operational risk related to failures in obligations to clients and/or product design.

\subsection{Tail Operational Risk}

Our analysis in the prior sections examined the association between operational risk and banking organization growth by modeling the conditional average (assets-scaled) operational losses. In contrast, this section focuses on the frequency of tail loss events. The distinction between experiencing a higher level of operational risk vis-à-vis tail operational loss events is important. Higher, but stable, operational losses have adverse implications for BHC profitability and performance but are easier to anticipate and reserve for. By contrast, operational tail losses pose difficulties for loss reserving practices and capital management, and are very relevant for BHC risk of failure.

As discussed in Section 2.2, we use three different definitions of BHC tail loss frequency over a given quarter: $N$ Tail 90, $N$ Tail 95 and $N$ Tail 99. The pairwise correlations in Table 2, Panel B provide some preliminary evidence that the faster growing banking organizations experience more tail events. We next show that these associations also persist in a multivariate setting. To accommodate the use of count-based dependent variables (i.e. tail loss 
frequencies), we use Negative Binomial (NB) regressions. Our specifications are otherwise similar to Equation 2. Table 6 presents the results.

[Insert Table 6 about here]

Faster growth is notably related to a higher frequency of tail risk events. Depending on the tail risk measure used, a one standard deviation increase of Asset Growth from its mean would result in 0.05-1.31 more tail risk events experienced by a $\mathrm{BHC}$ in a given quarter, or a $5.8-8.4 \%$ increase in relative terms. The coefficients of Asset Growth are positive and significant at least at the $5 \%$ level for each measure of tail operational risk.

\subsection{Global Financial Crisis}

The U.S. banking sector experienced massive operational losses during the 2007-09 global financial crisis (Abdymomunov et al. (2020)), although significant differences existed in the cross-section of banking organizations (Abdymomunov and Mihov (2019)). Understanding the sources of such differences is important for comprehending past and evaluating future system-wide risks. In this section, we investigate whether BHCs with faster growth prior to the crisis had larger operational losses during the crisis. On the one hand, significant growth in the pre-crisis period might have exposed banks to additional operational risks during the crisis through inadequately scaled (integrated in the case of M\&As) processes, systems, controls and employee workforces. On the other hand, pre-crisis bank growth might not have been related to the emergence of operational risks during crisis - large operational losses might have been unavoidable regardless.

To test this, we calculate Asset Growth 2005-06 as the average of Asset Growth over the period [2005:Q1-2006:Q4]. We then interact Asset Growth 2005-06 with the financial crisis indicator variable Financial Crisis 2007-09 (equal to 1 during the period [2007:Q4-2009:Q2], and 0 otherwise) and test the term's significance in a regression framework similar to Equa- 
tion 2. While our specifications separately include Asset Growth 2005-06 and Financial Crisis 200\%-09, the stand-alone coefficient of Asset Growth 2005-06 cannot be identified due to the inclusion of BHC fixed effects and is thus not reported. Table 7 presents results.

[Insert Table 7 about here]

The coefficient of Asset Growth 2005-06 * Financial Crisis 2007-09 in Column (1) is positive and significant at the $10 \%$ level. This suggests that indeed high banking organization growth in the pre-crisis period subsequently contributed to larger operational losses during the crisis. A one standard deviation increase in Asset Growth 2005-06 is associated with a $86.7 \%$ increase in LtA during the 2007-09 period relative to its unconditional mean. Column (2) shows that our results are also robust to a broader definition of the crisis period that spans [2007:Q4-2011:Q4].

\section{Additional Analyses and Robustness Checks}

This section provides additional robustness checks, which explore whether our main empirical findings are robust to endogeneity checks, alternative estimation methodologies, variable definitions, and additional control variables.

\subsection{Evidence from M\&A Event Studies}

As discussed in Section 3.1, M\&As are a primary mechanism through which banking organizations grow. Moreover, they are well-defined events that can plausibly be treated as exogenous growth shocks and otherwise orthogonal to operational risk (other than through growth-related channels). We use the list of previously identified M\&A events (from Section 3.1) in an event-study setting to identify whether these events result in higher operational losses. Our event study tests mitigate particular identification concerns that we are not 
capturing the relation between operational risk and $\mathrm{BHC}$ growth, but rather the relation between operational risk and some uncontrolled institution-specific effect.

We estimate the following regression specifications:

$$
\operatorname{Lt}_{i, m, t}=\beta_{i, m}+\beta_{1} \text { Post } \text { Merger }_{i, m, t}+\beta_{2} \text { Controls }_{i, m, t}+\epsilon_{i, m, t}
$$

where $i$ indexes BHCs, $m$ indexes M\&A events and $t$ indexes quarters before and after. We use several alternative window lengths around events: $1,2,3$, and 4 quarters. $L t A_{i, m, t}$ measures operational losses as a proportion of total assets that occur at BHC $i$ during quarter $t$. Post $M \& A_{i, m, t}$ is an indicator variable equal to 1 for the quarters of and following the M\&A consumption (consolidation of acquired entity $m$ into BHC $i$ ), and 0 otherwise. Controls $_{i, m, t}$ represents our previously discussed vector of BHC-level and macroeconomic control variables. We include M\&A event fixed effects $\left(\beta_{i, m}\right)$ and cluster standard errors at the M\&A event level. Table 8 present the results.

[Insert Table 8 about here]

Post MEA is positive and significant at the $5 \%$ level across specifications in Columns (1)-(4) using varying windows around an event. This suggests that operational losses (as a proportion of total assets) increase in the four quarters following a combination and is consistent with idea that merger and acquisition activity increases operational risk at banking organizations.

We next take a step further and test whether larger M\&As are associated with more operational risk. To study this issue, we calculate $M \mathscr{E} A$ Size (\%), which measures the asset size of the acquired company as a proportion of the acquiror's asset size one quarter prior to the consumption of the merger. We then estimate a model similar to Equation 4 but include interactions between Post MEA and MEA Size (\%). Due to the inclusion of M\&A event fixed effects, we are unable to identify the coefficient on $M \mathscr{G} A$ Size (\%) individually. 
Column (5) shows that indeed larger acquisitions are associated with more operational risk. The coefficient of the interaction term Post MEA * MEA Size (\%) is positive and significant at the $10 \%$ level.

\subsection{Instrumental Variables}

In addition to our event study analyses, we also estimate instrumental variable regressions as another approach to address endogeneity concerns. Our first instrument is the yearover-year growth in the number of BHC employees ( $N$ Employees Growth). While employee growth should be significantly positively correlated with the asset growth of a given firm, it should not be (positively) related to the occurrence of operational losses other than through the organizational growth channel. Our second instrument, Peer N Employees Growth, is a refinement of the first one and takes an additional step to mitigate the unlikely possibility that the correlation between asset growth and operational losses at a given $\mathrm{BHC}$ is driven by a latent firm-specific factor that determines both and is also correlated with BHC employee growth. Peer N Employees Growth is constructed as follows. For a BHC in a given quarter, we select the five institutions in our sample with closest asset growth. We then use the median employee growth of this group of peer banks as an instrument for the asset growth of the specific bank in a given quarter. Our explicit assumption for the validity of the instrument is thus that the median employee growth of matched institutions should not reflect the latent firm-specific characteristics that drive both operational losses and asset growth at the BHC for which the matched group is created. Table 9 presents the results.

[Insert Table 9 about here]

Table 9, Columns (1) and (2) present first-stage results. Our two instruments are strongly positively correlated with BHC growth and are highly statistically significant, suggesting that the IV regressions do not suffer from weak instrumental variable problems. Columns (3) and 
(4) present second-stage results. Here, we see that Asset Growth retains its positive sign and statistical significance at conventional levels. Our IV analysis, therefore, suggests that our main results are robust to accounting for omitted variable problems.

An additional identification concern could be that there is reverse causality stemming from operational losses to BHC growth (e.g., operational losses might reduce total assets through reputation and asset impairment channels). We note, however, that reverse causality is unlikely to be the driver of our results for two reasons. First, to the extent that such reverse causality implies a negative correlation between operational risk and BHC growth, it should only bias our results downwards against finding the positive relation that we do. Second, using lagged asset growth to match operational loss occurrence in our estimations suggests a feedback loop from losses to growth is conceptually impossible to have an impact in our specifications. ${ }^{11}$ We thus rule out this second identification concern but note that our M\&A event studies and instrumental variable estimations also serve to address any remaining reverse causality concerns.

\subsection{Time Fixed Effects}

Our baseline specification in Section 3.1 employs within-firm estimation (i.e. BHC fixed effects) to control for cross-sectional differences in operational losses and size growth. A natural question arises whether our results are driven by period-specific shocks. While we already control for the financial crisis period through an indicator variable and more generally the macroeconomic environment through GDP growth, potential industry-level shocks might not have been adequately captured by these controls. We next specifically show that our baseline results are robust to economic cycle fixed effects and even granular quarter fixed

\footnotetext{
${ }^{11} \mathrm{An}$ additional argument that invalidates reverse causality concerns given our empirical setup is that bank managers or outside investors do not know about operational losses until such losses are discovered (or accounted for). There are usually significant time lags (in the order of several years) between the occurrence and discovery of material operational losses that could plausibly result in feedback loops (Abdymomunov et al. (2020)).
} 
effects. Table 10, Columns (1) and (2) present results. Asset Growth remains positive and statistically significant at least at the $5 \%$ level in the presence of both economic cycle and quarter fixed effects.

[Insert Table 10 about here]

\subsection{Alternative Variable Definitions}

In this section, we check the robustness of our baseline results in Section 3.1 to alternative scaling of our main dependent variable, LtA. LtA is defined as the operational losses that occur at a BHC over a given calendar quarter scaled by a BHC's total assets (and multiplied by 1,000). Table 10, Columns (3) and (4) show that our results remain robust if we use alternative scaling factors for operational losses - e.g., gross income $(L t I)$ or total liabilities $(L t L)$.

We also show that our results are robust to alternative growth horizons of total assets growth. Asset Growth is defined as the year-over-year growth of assets. We calculate two alternatives: quarter-over-quarter growth (Asset Growth 1Q) and the two-year growth (Asset Growth 8Q). Columns (5) and (6) present the results.

\subsection{Additional Controls}

Throughout our study, we rely on the ratio of interest to non-interest income (II-to-NII), the ratio of deposits to assets (Deposits-to-Assets), the ratio of loans to assets (Loans-to-Assets) and BHC fixed effects to account for cross-sectional differences in exposure to business activities. In this section, we include a more detailed set of variables capturing business area exposures. Specifically, we include the proportion of revenue coming from: interest income on loans and leases (Loans and Leases), interest income on investment securities (Investment Securities), income from fiduciary activities (Fiduciary Activities), trading revenue (Trading), 
income from investment banking, advisory, brokerage and underwriting fees (Investment Banking), venture capital revenue (Venture Capital), securitization income (Securitization) and servicing fees revenue (Servicing Fees). Table 10, Column (7) shows our baseline results are robust to the inclusion of these additional controls.

\section{Channels of the Positive Relation between Banking Organization Growth and Operational Risk}

This section briefly discusses potential channels through which organizational growth may result in greater operational risks. First, growth could be fuelled by short-term incentives of BHC managers with high-powered compensation schemes tilted to current profits (e.g., Rajan (1994)). Such compensation schemes specifically induce managers to book business at the expense of potential future operational losses, which oftentimes take years to materialize from when they occur to when they get discovered (Abdymomunov et al. (2020), Chernobai et al. (2020)). In their push for growth, bank executives could set incentives that lead employees to engage in risky practices that are not directly observable by them. Alternatively, executives could be fully cognizant of the higher risk of the practices that employees engage in, but overlook that risk for better short-run performance. In either case, risky practices such as aggressive "cross-selling" of products, outright mis-selling (i.e. the deliberate or negligent sale of products or services in circumstances where the contract is either misrepresented, or the product or service is unsuitable for the customer's needs), and abusive deposit growth strategies (e.g., as in the Wells Fargo fake-account scandal) oftentimes result in significant regulatory fines and redress payments. ${ }^{12}$

We explore this channel with widely used measures of executive compensation incentives

\footnotetext{
${ }^{12}$ See Office of Attorney General: "Attorney General Shapiro Announces $\$ 575$ Million 50-State Settlement with Wells Fargo Bank for Opening Unauthorized Accounts and Charging Consumers for Unnecessary Auto Insurance, Mortgage Fees" (December 28, 2018).
} 
and board monitoring strength. First, we use a compensation-based measure of risk-taking incentives (vega) for corporate executives (Core and Guay (2002)). These data, provided to us by Coles et al. (2006), cover 26 of the BHCs in our sample over the period [20002014]. Formally, vega is defined as the dollar change in executive wealth associated with a 0.01 change in the standard deviation of the BHCs's returns (in $\$ 000 \mathrm{~s}$ ). We discretize the variable and define Execu Comp Vega as an indicator variable equal to 1 if vega for a BHC during a given quarter is greater than the sample median, and 0 otherwise. Second, we follow prior literature that has traditionally used the proportion of independent directors on a firm's board as a measure of board monitoring strength (e.g., Weisbach (1988), Brickley et al. (1994), Coles et al. (2008)). Our data on board independence come from the U.S. Spencer Stuart Board Index reports, which provide board statistics for 25 of the BHCs in our sample over the period [2004-2018]. ${ }^{13}$ Using these data, we define Board Independence as an indicator variable equal to 1 if the proportion of independent directors on a BHC's board during a given quarter is greater than the sample median, and 0 otherwise. ${ }^{14}$

As a next step, we interact Asset Growth with Execu Comp Vega and Board Independence, respectively, and test the terms' significance in a regression framework similar to Equation 2. Table 11, Columns (1) and (2) present the results. Consistent with the existence of this first channel, the coefficient of Asset Growth * Execu Comp Vega in Column (1) is positive and the coefficient of Asset Growth * Board Independence in Column (2) is negative (both significant at the $10 \%$ level). While institutions which provide executives with more risktaking incentives through compensation have amplified operational losses associated with BHC growth, enhanced board monitoring by independent directors appears to mitigate the positive effect of BHC growth on operational risk. We additionally point to our results in

\footnotetext{
${ }^{13}$ The latest U.S. Spencer Stuart Board Index report can be found at: https://www. spencerstuart. com/research-and-insight/us-board-index.

${ }^{14}$ Our measures of executive compensation incentives and board independence are available at the annual frequency. To match them to the rest of our data at the quarterly frequency, the annual value of a measure for a given BHC is assigned to all the quarters in that year for that BHC.
} 
Section 3.3, which indicate that the principal driver of the relation between operational risk and banking organization growth are breaches and failures in obligations to clients, faulty product design, and business practices. These results put into perspective and highlight credible types of operational losses caused by skewed compensation incentives and weak monitoring.

[Insert Table 11 about here]

Organizational growth can also strain managerial oversight, including risk surveillance (e.g., Brickley et al. (2003), Berger et al. (2005)), or even non-managerial employee resources. If growth is improperly "staffed," employees might spread their attention too thin over increasing job responsibilities or stretch internal rules and controls in order to complete their assignments. This could result in costly operational mistakes. Alternatively, if growth is accompanied by an expansion of the employee base, new workers may expose banking organizations to operational risks as they take time to properly train and gain adequate "on-the-job" experience.

We provide evidence on this second channel by exploring the correlation between the yearover-year growth in the number of BHC employees, $N$ Employees Growth, and operational risk in a regression specification similar to Equation 2. Table 11, Column (3) shows that employee growth is associated with higher operational losses - the coefficient of $N$ Employees Growth is positive and significant at the $1 \%$ level. ${ }^{15}$ To differentiate between growth that is insufficiently staffed versus rapid increase in the bank's employee base, we decompose Asset Growth into three variables: Asset Growth (Low Emp Growth), Asset Growth (Med Emp Growth) and Asset Growth (High Emp Growth). Asset Growth (Low Emp Growth) equals Asset Growth for observations where $N$ Employees Growth is in the lowest quartile

\footnotetext{
${ }^{15}$ We emphasize that employee growth is not a separate factor that amplifies operational losses associated with BHC (asset) growth, but rather it is inherent and related to BHC growth. Hence, we do not test this channel through interaction terms, nor do we control for Asset Growth in our specifications. The operational risk effects of employee growth are implicit in BHC size growth.
} 
of its distribution, 0 otherwise. Asset Growth (Med Emp Growth) equals Asset Growth for observations where $N$ Employees Growth is in the inner two quartiles of its distribution, 0 otherwise. Asset Growth (High Emp Growth) equals Asset Growth for observations where $N$ Employees Growth is in the highest quartile of its distribution, 0 otherwise. We then proceed to test the relation of these three variables with our main operational loss measure $L t A$.

The results in Column (4) show that the significantly positive relation between operational losses and asset growth is driven by observations where BHCs experience the highest employee growth. This finding supports the idea that rapid expansions of bank employee bases expose banking organizations to operational risks through inadequate oversight of growing employee bases, or as new workers lacking necessary job "know-how" and institutional knowledge make costly mistakes. A particular driver of the relationship between employee growth and operational risk can be organizational changes such as mergers and acquisitions (which often result in large increases in BHC employee bases). Such events can also spawn additional operational risks via mechanisms other than employees and staffing - for example, through failures in the system and process integration of the merging entities. Our results in Section 4.1 indeed highlight higher operational losses around M\&As and provide supporting evidence that M\&As are a significant source of operational risk. ${ }^{16}$

\section{Conclusion}

This study makes an important contribution to the growing research on operational risk at financial institutions and suggests that this risk might be a link in the nexus of firm growth and subsequent company performance. We focus on large U.S. BHCs for which a regulatory framework, the Dodd-Frank Act, provides us with rich and detailed data to carry out our

\footnotetext{
${ }^{16}$ While we do not test the following directly, we note that expanding into new business segments, adopting new technologies or engaging in new ways of conducting business to tap new markets without yet having proper control environments could similarly result in higher operational losses.
} 
empirical tests. Using a sample of 376,443 individual loss events from the 38 largest U.S. BHCs over the period [2001:Q1-2018:Q4], we present evidence that banking organization growth exposes banks to higher operational risk.

We show that BHCs whose assets grow faster have higher operational losses per dollar of assets. Event-study evidence and instrumental variables regression techniques confirm these results. The positive relationship between growth and operational risk is at least partially driven by a higher incidence of severe ("tail") risk events at high-growth banking organizations. Both organic growth and growth through M\&As are associated with higher operational losses. With respect to balance sheet categories, loan growth and deposit growth are principal drivers. The main type of operational losses that contribute to the positive empirical association between growth and operational risk are failures in obligations to clients, faulty product design, and business practices. Finally, we illustrate that banks with higher asset growth before the onset of the global financial crisis have higher operational losses during the crisis period.

We conclude that organizational growth is an important factor for banking institutions' operational risk profiles. Our study highlights a particular channel through which growth could lead to future under-performance, counteracting efficiencies arising from scale economies and drivers of growth such as IT advancements. Our study complements earlier literature that points to unexpected credit risk of financial institutions as an organizational growth externality. From a practitioner's perspective, our findings have implications for corporate risk management as well as policy and supervision. Our results suggest that quickly growing BHCs could benefit from tightening risk management practices with regards to operational risk. Our findings also implicitly suggest supervision approaches that subject the fastest growing financial institutions to enhanced supervisory scrutiny, heightened risk management and governance standards, and stricter capital adequacy expectations. 


\section{References}

Abdymomunov, A., Curti, F., and Mihov, A. (2020). U.S. banking sector operational losses and the macroeconomic environment. Journal of Money, Credit and Banking, 52(1):115144. https://doi.org/10.1111/jmcb.12661.

Abdymomunov, A. and Mihov, A. (2019). Operational risk and risk management quality: Evidence from U.S. bank holding companies. Journal of Financial Services Research, 56(1):73-93. https://doi.org/10.1007/s10693-017-0284-3.

Adams, R. and Driscoll, J. (2018). How the largest bank holding companies grew: Organic growth or acquisitions? FEDS Notes. Washington: Board of Governors of the Federal Reserve System, December 21, 2018. https://doi.org/10.17016/2380-7172.2282.

Afonso, G., Curti, F., and Mihov, A. (2019). Coming to terms with operational risk. Federal Reserve Bank of New York Liberty Street Economics.

Ahmed, A. S., Takeda, C., and Thomas, S. (1999). Bank loan loss provisions: A reexamination of capital management, earnings management and signaling effects. Journal of Accounting and Economics, 28(1):1-25. https://doi.org/10.1016/s0165-4101(99)000178.

Allen, L. and Bali, T. G. (2007). Cyclicality in catastrophic and operational risk measurements. Journal of Banking \& Finance, 31(4):1191-1235. https://doi.org/10.1016/j.jbankfin.2006.10.007.

Baron, M. and Xiong, W. (2017). Credit expansion and neglected crash risk. The Quarterly Journal of Economics, 132(2):713-764. https://doi.org/10.1093/qje/qjx004.

Basel Committee on Banking Supervision (2001). Working paper on the regulatory treatment of operational risk. Bank of International Settlements.

Basel Committee on Banking Supervision (2006). International convergence of capital measurement and capital standards. Bank of International Settlements.

Berger, A. N., Miller, N. H., Petersen, M. A., Rajan, R. G., and Stein, J. C. (2005). Does function follow organizational form? Evidence from the lending practices of large and small banks. Journal of Financial Economics, 76(2):237-269. https://doi.org/10.1016/j.jfineco.2004.06.003.

Betton, S., Eckbo, B. E., and Thorburn, K. S. (2008). Corporate takeovers. Handbook of Corporate Finance: Empirical Corporate Finance edited by B. Espen Eckbo. https://doi.org/10.1016/B978-0-444-53265-7.50007-X.

Brickley, J. A., Coles, J. L., and Terry, R. L. (1994). Outside directors and the adoption of poison pills. Journal of Financial Economics, 35(3):371-390. https://doi.org/10.1016/0304-405x(94)90038-8. 
Brickley, J. A., Linck, J. S., and Smith, C. W. (2003). Boundaries of the firm: evidence from the banking industry. Journal of Financial Economics, 70(3):351-383. https://doi.org/10.1016/s0304-405x(03)00170-3.

Brunnermeier, M. K., Dong, G. N., and Palia, D. (2020). Banks' non-interest income and systemic risk. Review of Corporate Finance Studies, Forthcoming.

Chernobai, A., Jorion, P., and Yu, F. (2011). The determinants of operational risk in U.S. financial institutions. The Journal of Financial and Quantitative Analysis, 46(6):16831725. https://doi.org/10.1017/s0022109011000500.

Chernobai, A., Ozdagli, A., and Wang, J. (2020). Business complexity and risk management: Evidence from operational risk events in U.S. bank holding companies. Journal of Monetary Economics, Forthcoming. https://doi.org/10.1016/j.jmoneco.2020.02.004.

Chernobai, A. and Rachev, S. (2006). Applying robust methods to operational risk modeling. Journal of Operational Risk, 1(1):27-41. https://doi.org/10.21314/jop.2006.003.

Coles, J. L., Daniel, N. D., and Naveen, L. (2006). Managerial incentives and risk-taking. Journal of Financial Economics, 79(2):431-468. https://doi.org/10.1016/j.jfineco.2004.09.004.

Coles, J. L., Daniel, N. D., and Naveen, L. (2008). Boards: Does one size fit all? Journal of Financial Economics, 87(2):329-356. https://doi.org/10.1016/j.jfineco.2006.08.008.

Cooper, M. J., Gulen, H., and Schill, M. J. (2008). Asset growth and the cross-section of stock returns. The Journal of Finance, 63(4):1609-1651. https://doi.org/10.1111/j.15406261.2008.01370.x.

Cope, E. W. and Carrivick, L. (2013). Effects of the financial crisis on banking operational losses. Journal of Operational Risk, 8(3):3-29. https://doi.org/10.21314/jop.2013.125.

Cope, E. W., Piche, M. T., and Walter, J. S. (2012). Macroenvironmental determinants of operational loss severity. Journal of Banking \&6 Finance, 36(5):1362-1380. https://doi.org/10.1016/j.jbankfin.2011.11.022.

Core, J. and Guay, W. (2002). Estimating the value of employee stock option portfolios and their sensitivities to price and volatility. Journal of Accounting Research, 40(3):613-630. https://doi.org/10.1111/1475-679x.00064.

Cummins, J. D., Lewis, C. M., and Wei, R. (2006). The market value impact of operational loss events for US banks and insurers. Journal of Banking \& Finance, 30(10):2605-2634. https://doi.org/10.1016/j.jbankfin.2005.09.015.

Curti, F., Frame, W. S., and Mihov, A. (2019). Are the largest banking organizations operationally more risky? Working Paper. https://doi.org/10.24149/wp2016. 
de Fontnouvelle, P., Dejesus-Rueff, V., Jordan, J. S., and Rosengren, E. S. (2006). Capital and risk: New evidence on implications of large operational losses. Journal of Money, Credit and Banking, 38(7):1819-1846. https://doi.org/10.1353/mcb.2006.0088.

Ellul, A. and Yerramilli, V. (2013). Stronger risk controls, lower risk: Evidence from U.S. bank holding companies. The Journal of Finance, 68(5):1757-1803. https://doi.org/10.1111/jofi.12057.

Fahlenbrach, R., Prilmeier, R., and Stulz, R. M. (2017). Why does fast loan growth predict poor performance for banks? The Review of Financial Studies, 31(3):1014-1063. https://doi.org/10.1093/rfs/hhx109.

Feng, G. and Serletis, A. (2010). Efficiency, technical change, and returns to scale in large U.S. banks: Panel data evidence from an output distance function satisfying theoretical regularity. Journal of Banking \& Finance, 34(1):127-138. https://doi.org/10.1016/j.jbankfin.2009.07.009.

Frame, W. S. and White, L. J. (2014). Technological change, financial innovation and diffusion in banking. Oxford Handbook of Banking, 2nd Edition edited by Allen Berger, Philip Molyneux, and John Wilson. https://doi.org/10.1093/oxfordhb/9780199688500.013.0011.

Gillet, R., Hubner, G., and Plunus, S. (2010). Operational risk and reputation in the financial industry. Journal of Banking \& Finance, 34(1):224-235. https://doi.org/10.1016/j.jbankfin.2009.07.020.

Hess, C. (2011). The impact of the financial crisis on operational risk in the financial services industry: Empirical evidence. The Journal of Operational Risk, 6(1):23-35. https://doi.org/10.21314/jop.2011.087.

Hou, K., Xue, C., and Zhang, L. (2014). Digesting Anomalies: An Investment Approach. The Review of Financial Studies, 28(3):650-705. https://doi.org/10.1093/rfs/hhu068.

Hughes, J. P. and Mester, L. J. (2013). Who said large banks don't experience scale economies? Evidence from a risk-return-driven cost function. Journal of Financial Intermediation, 22(4):559-585. https://doi.org/10.1016/j.jfi.2013.06.004.

James, C. (1991). The losses realized in bank failures. The Journal of Finance, 46(4):12231242. https://doi.org/10.1111/j.1540-6261.1991.tb04616.x.

Jarrow, R. A. (2008). Operational risk. Journal of Banking E Finance, 32(5):870-879. https://doi.org/10.1016/j.jbankfin.2007.06.006.

Jin, L. and Myers, S. C. (2006). $\mathrm{R}^{2}$ around the world: New theory and new tests. Journal of Financial Economics, 79(2):257-292. https://doi.org/10.1016/j.jineco.2004.11.003.

Jobst, A. (2007). Operational risk: The sting is still in the tail but the poison depends on the dose. The Journal of Operational Risk, 2(2):3-59. https://doi.org/10.21314/jop.2007.026. 
Kovner, A., Vickery, J., and Zhou, L. (2014). Do big banks have lower operating costs? Economic Policy Review, 20(2):1-27.

Polk, C. and Sapienza, P. (2008). The stock market and corporate investment: A test of catering theory. The Review of Financial Studies, 22(1):187-217. https://doi.org/10.1093/rfs/hhn030.

Rajan, R. G. (1994). Why bank credit policies fluctuate: A theory and some evidence. The Quarterly Journal of Economics, 109(2):399-441. https://doi.org/10.2307/2118468.

Rau, P. R. and Vermaelen, T. (1998). Glamour, value and the post-acquisition performance of acquiring firms. Journal of Financial Economics, 49(2):223-253. https://doi.org/10.1016/s0304-405x(98)00023-3.

Roll, R. (1986). The hubris hypothesis of corporate takeovers. The Journal of Business, 59(2):197-216. https://doi.org/10.1086/296325.

Wang, T. and Hsu, C. (2013). Board composition and operational risk events of financial institutions. Journal of Banking \& Finance, 37(6):2042-2051. https://doi.org/10.1016/j.jbankfin.2013.01.027.

Watanabe, A., Xu, Y., Yao, T., and Yu, T. (2013). The asset growth effect: Insights from international equity markets. Journal of Financial Economics, 108(2):529-563. https://doi.org/10.1016/j.jfineco.2012.12.002.

Weisbach, M. S. (1988). Outside directors and CEO turnover. Journal of Financial Economics, 20:431-460. https://doi.org/10.1016/0304-405x(88)90053-0.

Wheelock, D. C. and Wilson, P. W. (2012). Do large banks have lower costs? New estimates of returns to scale for U.S. banks. Journal of Money, Credit and Banking, 44(1):171-199. https://doi.org/10.1111/j.1538-4616.2011.00472.x. 


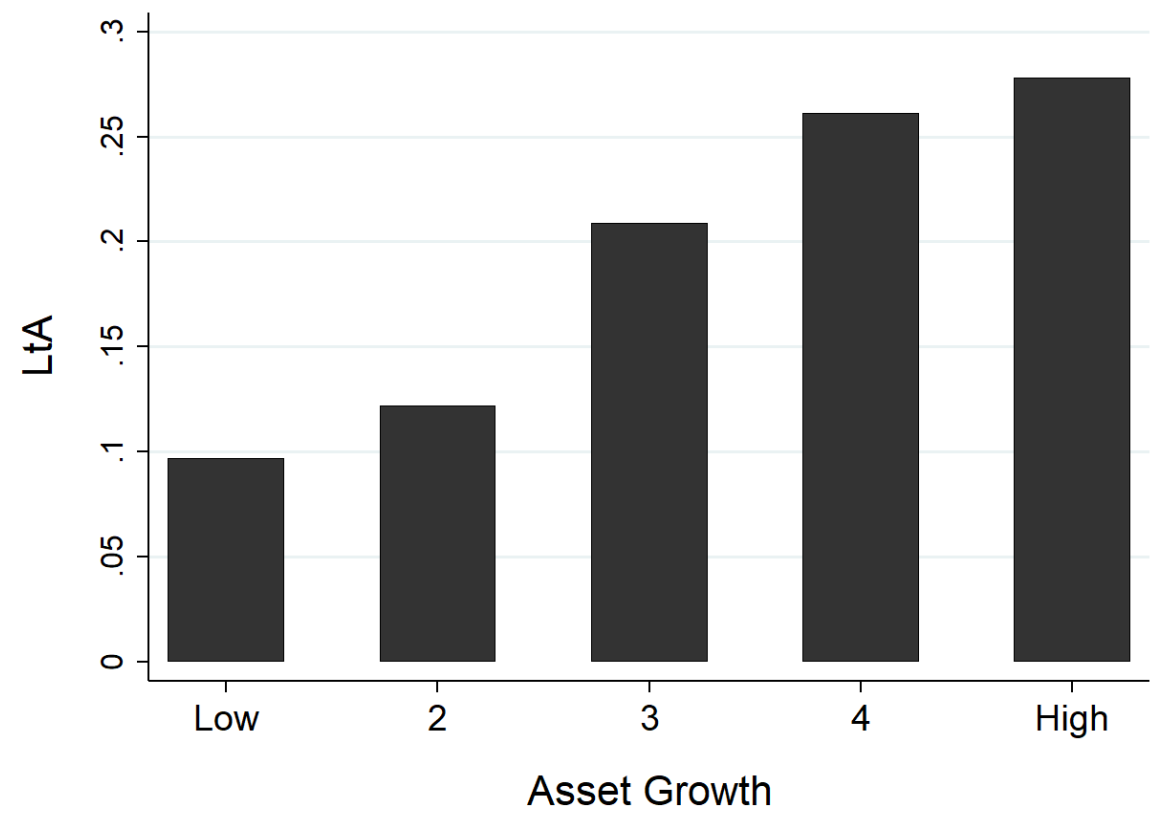

Figure 1: Operational Losses per Dollar of Assets by Asset Growth Groups

This figure presents a bar chart of the average ratio of operational losses to total assets (multiplied by 1,000), LtA, for BHCs sorted in quintiles based on total asset growth: "Low", "2", "3", "4" and "High". The chart presents the average LtA across the five groups of holding companies. The sample comprises an unbalanced panel of 1,644 quarterly observations of 38 large U.S. bank holding companies over the period [2001:Q1-2018:Q4]. 


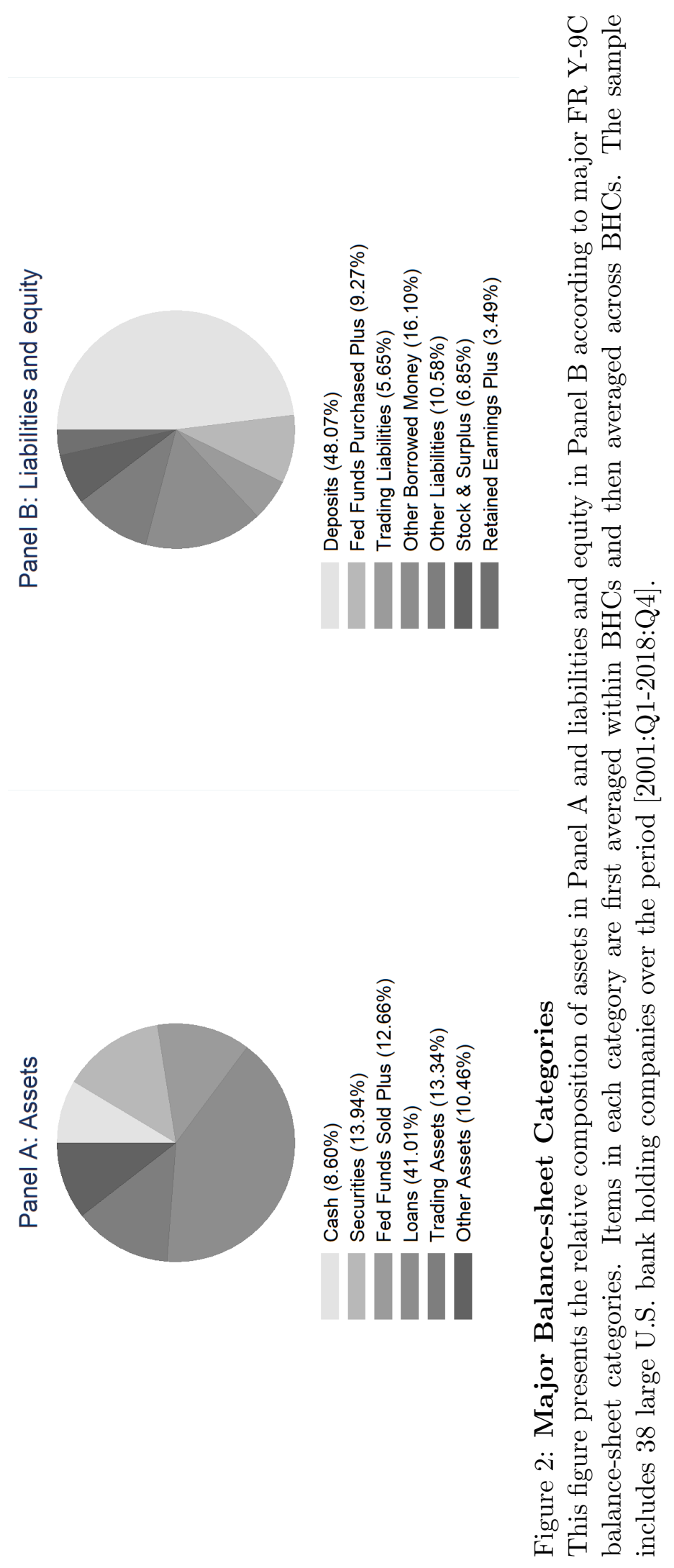




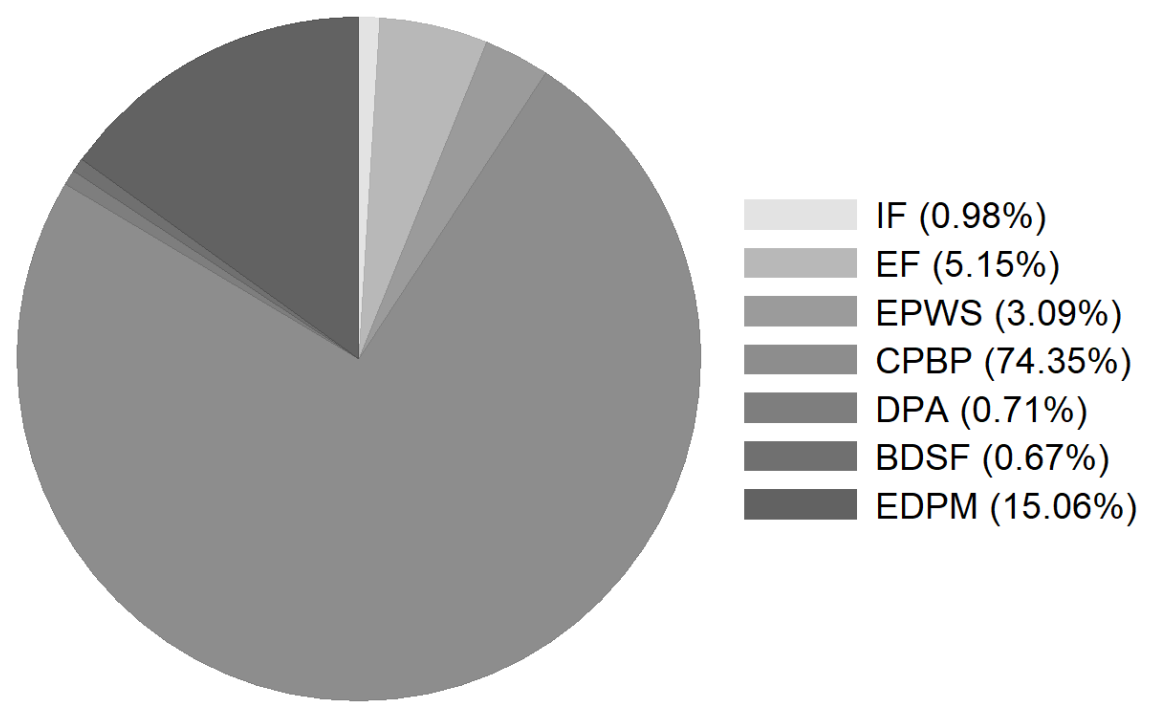

Figure 3: Operational Losses by Event Type

This figure presents the percentage allocation of losses according among the 7 operational risk event type categories. Losses in each category are first averaged within BHCs and then averaged across BHCs. The nomenclature for event types is as follows: Internal Fraud (IF), External Fraud (EF), Employment Practices and Workplace Safety (EPWS), Clients, Products and Business Practices (CPBP), Damage to Physical Assets (DPA), Business Disruption and System Failures (BDSF), and Execution, Delivery and Process Management (EDPM). The sample includes 376,443 operational losses incurred by 38 large U.S. bank holding companies over the period [2001:Q1-2018:Q4]. 
Table 1: Operational Loss Event Type and Variable Definitions

This table presents variable definitions in Panel A and operational loss event type definitions according to Basel Committee on Banking Supervision (2006) in Panel B.

\begin{tabular}{l}
\hline Panel A: Variable Definitions \\
\hline Variable \\
\hline Assets \\
Asset Growth (1Q, 8Q) \\
Asset Growth 2005-06 \\
Asset Growth (Low Emp Growth, \\
Med Emp Growth, High Emp \\
Growth)
\end{tabular}

Asset Growth (M\&A, Organic)

Definition

BHC total assets in billions of U.S. Dollars

Asset Growth is the year-over-year growth of BHC total assets. Asset Growth $1 Q$ is the quarter-over-quarter growth of $\mathrm{BHC}$ total assets. Asset Growth $8 Q$ is the two-year growth of BHC total assets

A BHC's average Asset Growth over [2005:Q1-2006:Q4]

Asset Growth (Low Emp Growth) equals Asset Growth if $N$ Employees Growth is in the lowest quartile of $N$ Employees Growth's distribution, 0 otherwise. Asset Growth (Med Emp Growth) equals Asset Growth if $N$ Employees Growth is in the two inner quartiles of $N$ Employees Growth's distribution, 0 otherwise. Asset Growth (High Emp Growth) equals Asset Growth if $N$ Employees Growth is in highest quartile of $N$ Employees Growth's distribution, 0 otherwise.

Asset Growth (MEA) is the year-over-year growth of BHC total assets achieved through M\&A activity. Asset Growth (Organic) is the residual year-over-year growth of $\mathrm{BHC}$ total assets that is not achieved through M\&A activity

Asset Growth (Positive, Negative) Asset Growth (Positive) equals Asset Growth if Asset Growth is $>=0,0$ otherwise. Asset Growth (Negative) equals Asset Growth if Asset Growth is $<0,0$ otherwise

Board Independence

An indicator variable that equals 1 if the proportion of independent directors on a BHC's board is greater than the sample median, 0 otherwise.

Cash Growth

Year-over-year growth of BHC cash and balances due from depository institutions

Deposits-to-Assets

The ratio of BHC deposits to total assets

Deposit Growth

Execu Comp Vega

Year-over-year growth of BHC deposits

An indicator variable that equals 1 if vega (a compensationbased measure of BHC executive risk-taking incentives) is greater than the sample median, 0 otherwise.

Fed Funds Purchased Plus Growth Year-over-year growth of BHC federal funds purchased and securities sold under agreements to repurchase

Fed Funds Sold Plus Growth

Year-over-year growth of BHC federal funds sold and securities purchased under agreements to resell 


\begin{tabular}{|c|c|}
\hline Panel A: Continued... & \\
\hline Variable & Definition \\
\hline Financial Crisis (2007-09, 2007-11) & $\begin{array}{l}\text { Financial Crisis } 2007-09 \text { is an indicator variable that equals } \\
1 \text { during the periods [2007:Q4-2009:Q2], and } 0 \text { otherwise. Fi- } \\
\text { nancial Crisis 2007-11 is an indicator variable that equals } 1 \\
\text { during the periods [2007:Q4-2011:Q4], and } 0 \text { otherwise. }\end{array}$ \\
\hline GDP Growth & Year-over-year U.S. real GDP growth rate \\
\hline II-to-NII & The ratio of $\mathrm{BHC}$ interest income to non-interest income \\
\hline Loans-to-Assets & The ratio of $\mathrm{BHC}$ loans to total assets \\
\hline Loan Growth & $\begin{array}{l}\text { Year-over-year growth of BHC loans and lease financing receiv- } \\
\text { ables }\end{array}$ \\
\hline Loan Losses & BHC loan charge-off rate \\
\hline Loss & $\begin{array}{l}\text { Operational losses that occur at a BHC over a given calendar } \\
\text { quarter in millions of U.S. Dollars }\end{array}$ \\
\hline $\operatorname{Ln}$ (Assets) & A natural log transformation of Assets \\
\hline $\operatorname{Ln}($ Loss $)$ & A natural log transformation of Loss \\
\hline LtA & $\begin{array}{l}\text { Operational losses that occur at a BHC over a given calen- } \\
\text { dar quarter as a proportion of the BHC's lagged total assets, } \\
\text { multiplied by } 1,000\end{array}$ \\
\hline LtI & $\begin{array}{l}\text { Operational losses that occur at a BHC over a given calendar } \\
\text { quarter as a proportion of the BHC's lagged gross income, } \\
\text { multiplied by } 1,000\end{array}$ \\
\hline LtL & $\begin{array}{l}\text { Operational losses that occur at a BHC over a given calendar } \\
\text { quarter as a proportion of the BHC's lagged total liabilities, } \\
\text { multiplied by } 1,000\end{array}$ \\
\hline Maturity Gap & $\begin{array}{l}\text { A natural log transformation of the absolute difference between } \\
\text { all assets that either reprice or mature within a year and all } \\
\text { the liabilities that reprice or mature within a year }\end{array}$ \\
\hline M\&A Size (\%) & $\begin{array}{l}\text { The asset size of an acquired company as a proportion of the } \\
\text { BHC's asset size } 1 \text { quarter prior to the merger }\end{array}$ \\
\hline N Employees & BHC number of employees in thousands \\
\hline N Employees Growth & Year-over-year growth of the number of BHC employees \\
\hline N Tail $(90,95,99)$ & $\begin{array}{l}\text { The frequency of total assets-scaled tail operational losses at } \\
\text { the } 90^{\text {th }}, 95^{\text {th }} \text { or } 99^{\text {th }} \text { percentiles, respectively, that occur at a } \\
\text { BHC over a given calendar quarter }\end{array}$ \\
\hline Other Assets Growth & $\begin{array}{l}\text { Year-over-year growth of BHC assets other than cash and bal- } \\
\text { ances due from depository institutions, securities, federal funds } \\
\text { sold and securities purchased under agreements to resell, loans } \\
\text { and lease financing receivables and trading assets. }\end{array}$ \\
\hline
\end{tabular}


Panel A: Continued...

\begin{tabular}{ll}
\hline Variable & Definition \\
\hline Other Borrowed Money Growth & Year-over-year growth of BHC other borrowed money \\
Other Equity Growth & $\begin{array}{l}\text { Year-over-year growth of BHC equity other than stock, surplus } \\
\text { and retained earnings }\end{array}$ \\
Other Liabilities Growth & $\begin{array}{l}\text { Year-over-year growth of BHC liabilities other than deposits, } \\
\text { federal funds purchased and securities sold under agreements } \\
\text { to repurchase and other borrowed money }\end{array}$ \\
Peer N Employees Growth & $\begin{array}{l}\text { The median year-over-year growth in the number of BHC em- } \\
\text { ployees of the } 5 \text { BHCs with closest asset growth to a given }\end{array}$ \\
BHC & $\begin{array}{l}\text { An indicator variable that equals 1 post an M\&A event, and 0 } \\
\text { otherwise }\end{array}$ \\
Post M\&A & Year-over-year growth of BHC retained earnings \\
Retained Earnings Growth & BHC return on equity, define as the ratio of net income to book \\
ROE & value of equity \\
Securities Growth & $\begin{array}{l}\text { Year-over-year growth of BHC securities (held-to-maturity, } \\
\text { available-for-sale and equity) held by a BHC }\end{array}$ \\
Stock \& Surplus Growth & $\begin{array}{l}\text { Year-over-year growth of BHC preferred stock, common stock } \\
\text { and related surplus }\end{array}$ \\
Tier 1 Capital & BHC tier 1 risk-based capital ratio \\
Trading Assets Growth & Year-over-year growth of BHC trading assets \\
Trading Liabilities Growth & Year-over-year growth of BHC trading liabilities \\
\hline
\end{tabular}




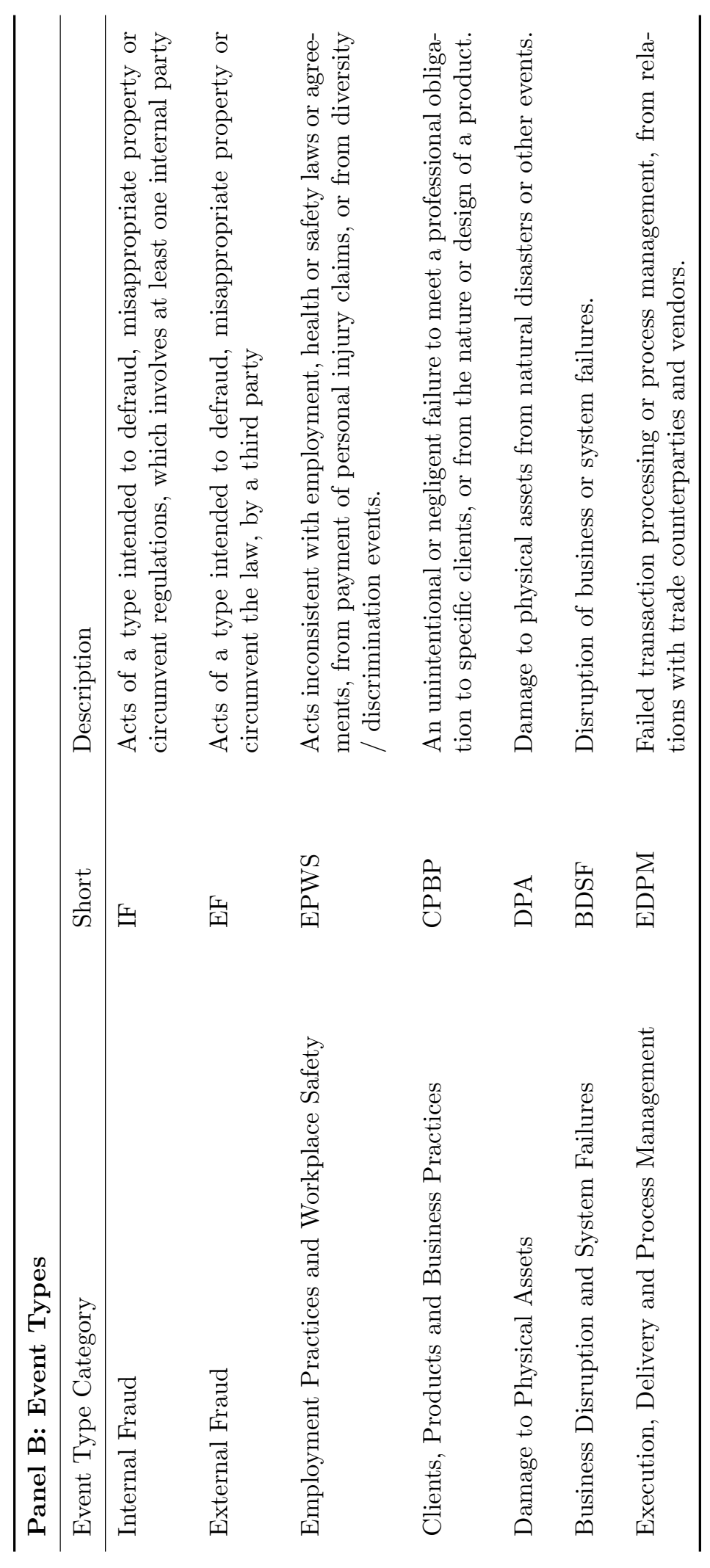


Table 2: Variable Descriptive Statistics and Correlations

This table presents variable descriptive statistics and correlations. The sample includes 1,644 quarterly observations of 38 large U.S. bank holding companies over the period [2001:Q1-2018:Q4] for which requisite data is available. The definitions of all variables are reported in Table 1. Panel A presents descriptive statistics. Panel B presents variable correlations.

\begin{tabular}{lcccccc}
\hline \multicolumn{2}{l}{ Panel A: Descriptive Statistics } & & & & & \\
\hline & Mean & SD & P25 & P50 & P75 & N \\
\hline Op Risk Variables: & & & & & & \\
\hline LtA & 0.240 & 0.882 & 0.031 & 0.068 & 0.159 & 1644 \\
Loss & 181.713 & 1353.766 & 4.124 & 12.094 & 55.253 & 1644 \\
N Tail 90 & 21.367 & 21.347 & 9.000 & 15.000 & 25.000 & 1644 \\
N Tail 95 & 10.616 & 10.714 & 4.000 & 8.000 & 13.000 & 1644 \\
N Tail 99 & 2.088 & 2.537 & 0.000 & 1.000 & 3.000 & 1644 \\
\hline Other Variables: & & & & & & \\
\hline Asset Growth & 0.073 & 0.168 & -0.001 & 0.042 & 0.098 & 1644 \\
Asset Growth (Positive) & 0.087 & 0.155 & 0.000 & 0.042 & 0.098 & 1644 \\
Asset Growth (Negative) & -0.014 & 0.040 & -0.001 & 0.000 & 0.000 & 1644 \\
Asset Growth (M\&A) & 0.041 & 0.144 & 0.000 & 0.000 & 0.000 & 1644 \\
Asset Growth (Organic) & 0.032 & 0.140 & -0.013 & 0.029 & 0.074 & 1644 \\
Asset Growth 2005-06 & 0.167 & 0.134 & 0.054 & 0.137 & 0.228 & 1150 \\
Assets & 419.869 & 617.416 & 85.605 & 144.648 & 350.188 & 1644 \\
Ln(Assets) & 5.277 & 1.146 & 4.450 & 4.974 & 5.858 & 1644 \\
II-to-NII & 1.960 & 5.714 & 1.173 & 1.802 & 2.723 & 1644 \\
Deposits-to-Assets & 0.604 & 0.184 & 0.521 & 0.664 & 0.735 & 1644 \\
Loans-to-Assets & 0.534 & 0.206 & 0.393 & 0.621 & 0.689 & 1644 \\
ROE & 0.019 & 0.031 & 0.011 & 0.021 & 0.030 & 1644 \\
Tier 1 Capital & 8.769 & 2.357 & 7.185 & 8.740 & 10.120 & 1644 \\
Loan Losses & 0.305 & 0.367 & 0.081 & 0.159 & 0.418 & 1644 \\
Maturity Gap & 17.726 & 1.326 & 16.891 & 17.616 & 18.443 & 1644 \\
GDP Growth & 0.019 & 0.016 & 0.015 & 0.021 & 0.027 & 1644 \\
Financial Crisis 2007-09 & 0.097 & 0.296 & 0.000 & 0.000 & 0.000 & 1644 \\
Financial Crisis 2007-11 & 0.273 & 0.445 & 0.000 & 0.000 & 1.000 & 1644 \\
N Employees Growth & 0.031 & 0.154 & -0.027 & 0.002 & 0.045 & 1644 \\
\hline
\end{tabular}




\begin{tabular}{lcccccc}
\hline Panel B: Correlations & & & & & \\
\hline \multicolumn{1}{c}{ Variables } & LtA & Ln(Loss) & 90 & 95 & 99 & $\begin{array}{c}\text { N Tail } \\
\text { Growth }\end{array}$ \\
\hline LtA & 1.000 & & & & & \\
& & & & & & \\
Ln(Loss) & 0.435 & 1.000 & & & & \\
& $(0.000)$ & & & & & \\
N Tail 90 & 0.225 & 0.444 & 1.000 & & & \\
& $(0.000)$ & $(0.000)$ & & & & \\
N Tail 95 & 0.241 & 0.459 & 0.931 & 1.000 & & \\
& $(0.000)$ & $(0.000)$ & $(0.000)$ & & & \\
N Tail 99 & 0.287 & 0.547 & 0.615 & 0.716 & 1.000 & \\
& $(0.000)$ & $(0.000)$ & $(0.000)$ & $(0.000)$ & & \\
Asset Growth & 0.106 & 0.119 & 0.068 & 0.080 & 0.085 & 1.000 \\
& $(0.000)$ & $(0.000)$ & $(0.006)$ & $(0.001)$ & $(0.001)$ & \\
\hline
\end{tabular}




\section{Table 3: Operational Losses and BHC Growth}

This table reports coefficients from panel regressions of operational losses on BHC asset growth and control variables. The estimation sample comprises an unbalanced panel of 1,644 quarterly observations of 38 large U.S. bank holding companies over the period [2001:Q1-2018:Q4]. LtA measures the operational losses that occur at a BHC over a given calendar quarter as a proportion of the BHC's total assets, multiplied by 1,000. Ln(Loss) is a natural log transformation of operational dollar losses that occur at a BHC over a given calendar quarter. Asset Growth is the year-over-year growth of BHC total assets. Asset Growth (Positive) equals Asset Growth if Asset Growth>=0, 0 otherwise. Asset Growth (Negative) equals Asset Growth if Asset Growth $<0,0$ otherwise. Asset Growth (MEAA) is the year-over-year growth of BHC total assets achieved through M\&A activity. Asset Growth (Organic) is the residual year-over-year growth of BHC total assets that is not achieved through M\&A activity. The definitions of all variables are reported in Table 1. All

specifications include BHC fixed effects. The error terms are clustered at the BHC and quarter levels. $p$-values are presented in parentheses. 


\begin{tabular}{|c|c|c|c|c|}
\hline & $\begin{array}{l}(1) \\
\text { LtA }\end{array}$ & $\begin{array}{c}(2) \\
\operatorname{Ln}(\text { Loss })\end{array}$ & $\begin{array}{r}(3) \\
\text { LtA }\end{array}$ & $\begin{array}{l}(4) \\
\text { LtA }\end{array}$ \\
\hline Asset Growth & $\begin{array}{l}0.340^{* * *} \\
(0.004)\end{array}$ & $\begin{array}{c}0.579^{* *} \\
(0.043)\end{array}$ & & \\
\hline Asset Growth (Positive) & & & $\begin{array}{l}0.369^{* * *} \\
(0.009)\end{array}$ & \\
\hline Asset Growth (Negative) & & & $\begin{array}{r}-0.039 \\
(0.929)\end{array}$ & \\
\hline Asset Growth (M\&A) & & & & $\begin{array}{c}0.334^{* *} \\
(0.020)\end{array}$ \\
\hline Asset Growth (Organic) & & & & $\begin{array}{l}0.221^{* *} \\
(0.023)\end{array}$ \\
\hline $\operatorname{Ln}$ (Assets) & $\begin{array}{r}-0.144^{*} \\
(0.092)\end{array}$ & $\begin{array}{c}0.265 \\
(0.308)\end{array}$ & $\begin{array}{r}-0.143^{*} \\
(0.092)\end{array}$ & $\begin{array}{c}-0.145^{* *} \\
(0.045)\end{array}$ \\
\hline II-to-NII & $\begin{array}{l}0.003^{* *} \\
(0.012)\end{array}$ & $\begin{array}{c}0.002 \\
(0.467)\end{array}$ & $\begin{array}{c}0.003 \\
(0.166)\end{array}$ & $\begin{array}{c}0.002 \\
(0.103)\end{array}$ \\
\hline Deposits-to-Assets & $\begin{array}{c}0.082 \\
(0.814)\end{array}$ & $\begin{array}{c}-2.423 \\
(0.101)\end{array}$ & $\begin{array}{c}0.083 \\
(0.809)\end{array}$ & $\begin{array}{c}0.036 \\
(0.911)\end{array}$ \\
\hline Loans-to-Assets & $\begin{array}{c}0.382 \\
(0.497)\end{array}$ & $\begin{array}{c}0.495 \\
(0.591)\end{array}$ & $\begin{array}{c}0.379 \\
(0.499)\end{array}$ & $\begin{array}{c}0.228 \\
(0.538)\end{array}$ \\
\hline $\mathrm{ROE}$ & $\begin{array}{c}0.659 \\
(0.286)\end{array}$ & $\begin{array}{c}0.401 \\
(0.753)\end{array}$ & $\begin{array}{c}0.665 \\
(0.286)\end{array}$ & $\begin{array}{c}0.216 \\
(0.631)\end{array}$ \\
\hline Tier 1 Capital & $\begin{array}{c}-0.023 \\
(0.163)\end{array}$ & $\begin{array}{c}-0.074 \\
(0.187)\end{array}$ & $\begin{array}{c}-0.023 \\
(0.141)\end{array}$ & $\begin{array}{c}-0.021 \\
(0.227)\end{array}$ \\
\hline Loan Losses & $\begin{array}{c}0.199 \\
(0.124)\end{array}$ & $\begin{array}{l}0.706^{* * *} \\
(0.009)\end{array}$ & $\begin{array}{c}0.190 \\
(0.145)\end{array}$ & $\begin{array}{c}0.193^{*} \\
(0.084)\end{array}$ \\
\hline Maturity Gap & $\begin{array}{c}-0.032 \\
(0.403)\end{array}$ & $\begin{array}{c}-0.051 \\
(0.592)\end{array}$ & $\begin{array}{c}-0.031 \\
(0.415)\end{array}$ & $\begin{array}{c}-0.021 \\
(0.486)\end{array}$ \\
\hline GDP Growth & $\begin{array}{l}1.270 \\
(0.613)\end{array}$ & $\begin{array}{c}-0.323 \\
(0.920)\end{array}$ & $\begin{array}{l}1.379 \\
(0.596)\end{array}$ & $\begin{array}{r}-0.009 \\
(0.995)\end{array}$ \\
\hline Financial Crisis 2007-09 & $\begin{array}{r}0.355^{*} \\
(0.077)\end{array}$ & $\begin{array}{r}0.386^{*} \\
(0.051)\end{array}$ & $\begin{array}{r}0.357^{*} \\
(0.089)\end{array}$ & $\begin{array}{r}0.158^{*} \\
(0.098)\end{array}$ \\
\hline N Obs & 1644 & 1644 & 1644 & 1644 \\
\hline $\operatorname{Adj} R^{2}$ & 0.07 & 0.70 & 0.06 & 0.06 \\
\hline
\end{tabular}




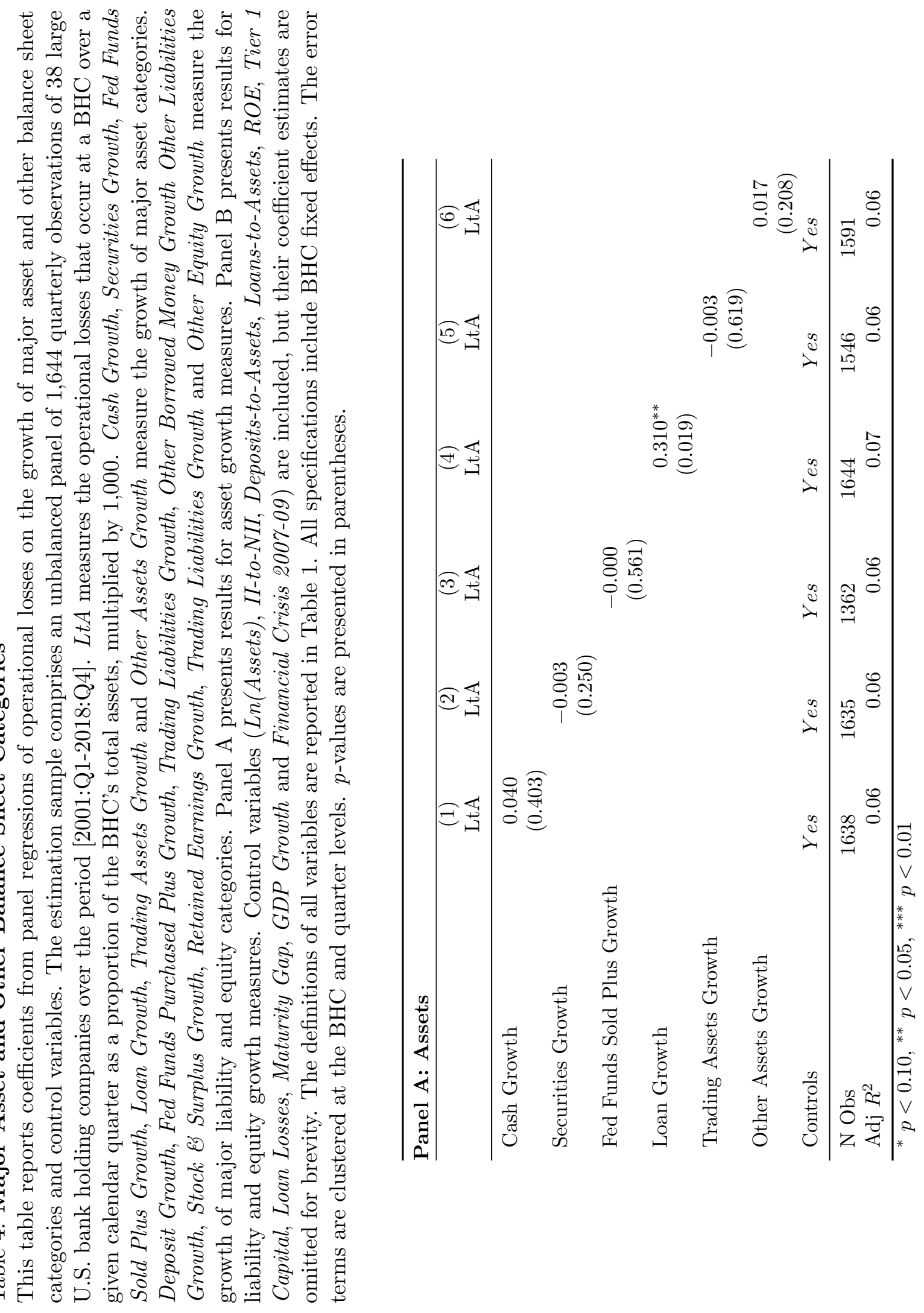




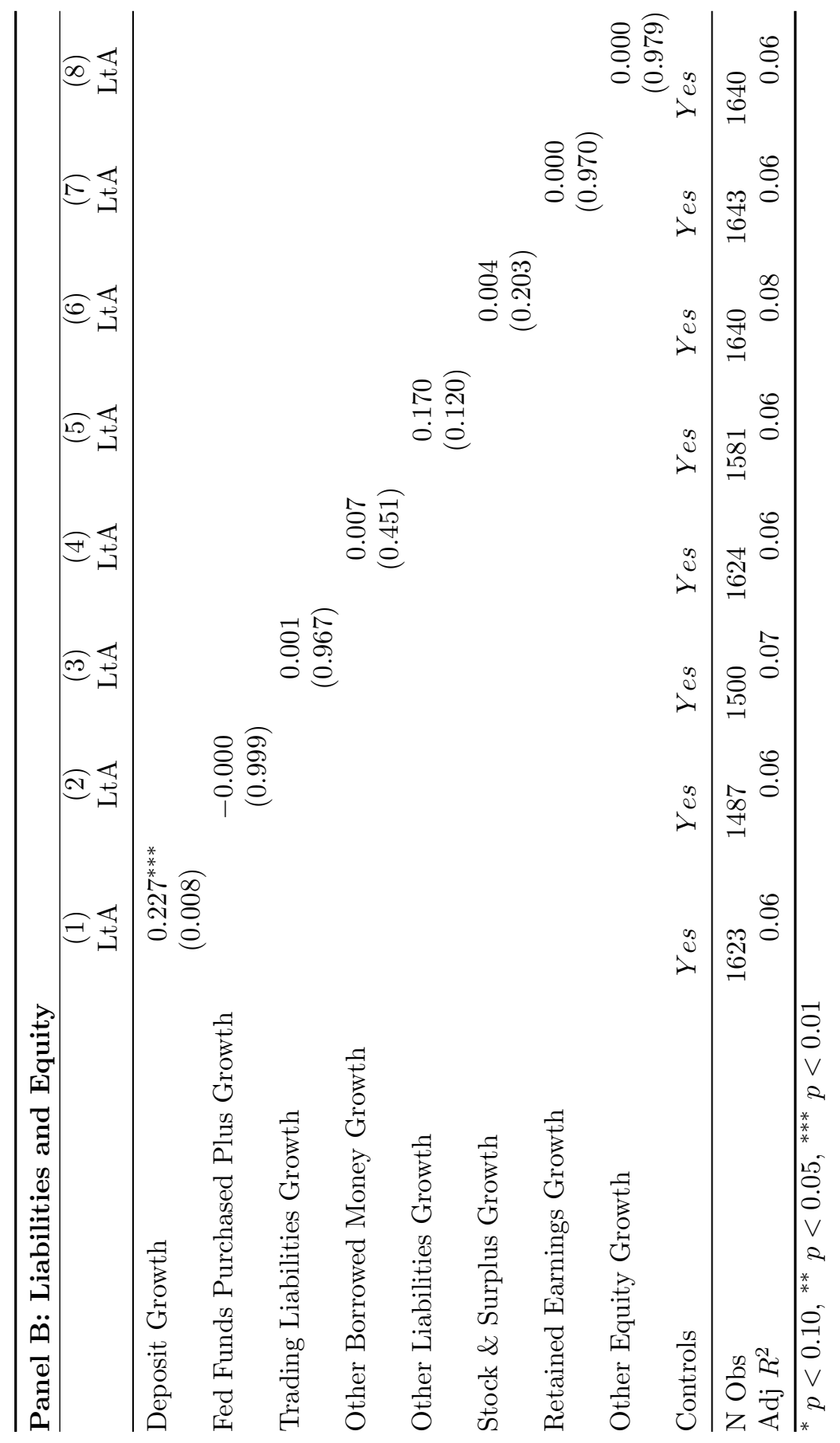




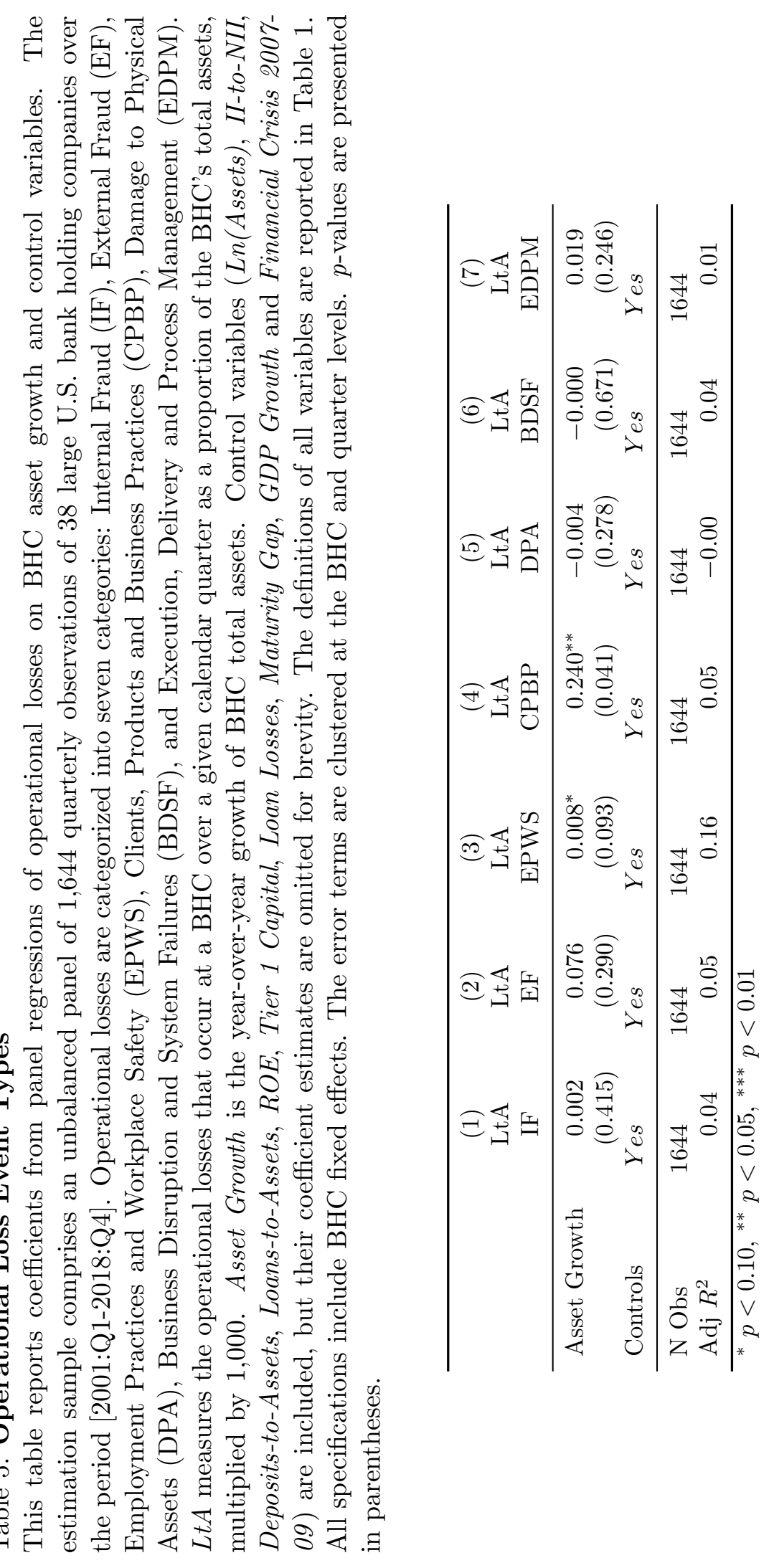


Table 6: Tail Operational Risk

This table reports coefficients from regressions of tail operational losses on BHC asset growth and control variables. The estimation sample comprises an unbalanced panel of 1,644 quarterly observations of 38 large U.S. bank holding companies over the period [2001:Q1-2018:Q4]. N Tail 95, $N$ Tail 99 and $N$ Tail 99.9 measure the frequency of assets-scaled tail operational losses at the $90^{\text {th }}, 95^{\text {th }}$ and $99^{\text {th }}$ quantiles, respectively, that occur at a BHC over a given calendar quarter. Asset Growth is the year-over-year growth of BHC total assets. The definitions of all variables are reported in Table 1. All specifications are estimated via Negative Binomial regression with BHC fixed effects. $p$-values are presented in parentheses.

\begin{tabular}{lccc}
\hline & $(1)$ & $(2)$ & $(3)$ \\
& N Tail 90 & N Tail 95 & N Tail 99 \\
\hline Asset Growth & $0.481^{* * *}$ & $0.479^{* * *}$ & $0.333^{* *}$ \\
& $(0.000)$ & $(0.003)$ & $(0.031)$ \\
Ln(Assets) & $-0.678^{* * *}$ & $-0.671^{* * *}$ & $-0.651^{* * *}$ \\
& $(0.000)$ & $(0.000)$ & $(0.000)$ \\
II-to-NII & -0.000 & 0.001 & 0.000 \\
& $(0.887)$ & $(0.301)$ & $(0.888)$ \\
Deposits-to-Assets & $-1.013^{* * *}$ & $-1.391^{* * *}$ & $-2.454^{* * *}$ \\
& $(0.000)$ & $(0.000)$ & $(0.000)$ \\
Loans-to-Assets & $1.354^{* * *}$ & $1.417^{* * *}$ & $1.112^{* *}$ \\
& $(0.000)$ & $(0.000)$ & $(0.015)$ \\
ROE & $0.987^{* *}$ & 0.735 & 0.399 \\
& $(0.043)$ & $(0.110)$ & $(0.635)$ \\
Tier 1 Capital & $-0.026^{* *}$ & -0.020 & -0.004 \\
& $(0.045)$ & $(0.164)$ & $(0.862)$ \\
Loan Losses & $0.410^{* * *}$ & $0.293^{* * *}$ & $0.285^{* * *}$ \\
Maturity Gap & $(0.000)$ & $(0.000)$ & $(0.001)$ \\
GDP Growth & -0.036 & $-0.069^{* *}$ & -0.054 \\
& $(0.258)$ & $(0.048)$ & $(0.251)$ \\
Financial Crisis $2007-09$ & 0.768 & 0.035 & 0.391 \\
& $(0.423)$ & $(0.974)$ & $(0.807)$ \\
& $0.146^{* *}$ & $0.121^{*}$ & $0.269^{* * *}$ \\
N Obs & $(0.021)$ & $(0.091)$ & $(0.002)$ \\
\hline${ }^{*} p<0.10{ }^{* *} p<0.05,^{* * *} p<0.01$ & 1644 & 1644 \\
\hline
\end{tabular}




\section{Table 7: Global Financial Crisis}

This table reports coefficients from panel regressions of operational losses on BHC asset growth and control variables. The estimation sample comprises an unbalanced panel of 1,150 quarterly observations of 19 large U.S. bank holding companies over the period [2001:Q1-2018:Q4] with requisite asset growth data over the period [2005:Q1-2006:Q4]. LtA measures the operational losses that occur at a BHC over a given calendar quarter as a proportion of the BHC's total assets, multiplied by 1,000. Asset Growth is the year-over-year growth of BHC total assets. Asset Growth 2005-06 is a banking holding company's average Asset Growth over [2005:Q1-2006:Q4]. Financial Crisis 2007-09 is an indicator variable that equals 1 during the periods [2007:Q4-2009:Q2], and 0 otherwise. Financial Crisis 200\%-11 is an indicator variable that equals 1 during the periods [2007:Q4-2011:Q4], and 0 otherwise. Control variables (Ln(Assets), II-to-NII, Deposits-to-Assets, Loans-to-Assets, ROE, Tier 1 Capital, Loan Losses, Maturity Gap, GDP Growth and Financial Crisis 2007-09) are included, but their coefficient estimates are omitted for brevity. The definitions of all variables are reported in Table 1. All specifications include BHC fixed effects. The error terms are clustered at the BHC and quarter levels. $p$-values are presented in parentheses.

\begin{tabular}{|c|c|c|}
\hline & $\begin{array}{c}(1) \\
\text { LtA }\end{array}$ & $\begin{array}{c}(2) \\
\text { LtA }\end{array}$ \\
\hline Asset Growth & $\begin{array}{c}0.459^{*} \\
(0.062)\end{array}$ & $\begin{array}{c}0.526^{* *} \\
(0.040)\end{array}$ \\
\hline Financial Crisis 2007-09 & $\begin{array}{c}0.140 \\
(0.349)\end{array}$ & \\
\hline Asset Growth 2005-06 * Financial Crisis 2007-09 & $\begin{array}{l}1.552^{*} \\
(0.089)\end{array}$ & \\
\hline Financial Crisis 2007-11 & & $\begin{array}{c}0.055 \\
(0.663)\end{array}$ \\
\hline Asset Growth 2005-06 * Financial Crisis 2007-11 & & $\begin{array}{c}0.982^{*} \\
(0.058)\end{array}$ \\
\hline Controls & Yes & Yes \\
\hline $\begin{array}{l}\text { N Obs } \\
\text { Adj } R^{2}\end{array}$ & $\begin{array}{l}1150 \\
0.07\end{array}$ & $\begin{array}{r}1150 \\
0.06\end{array}$ \\
\hline
\end{tabular}


Table 8: Evidence from Mergers and Acquisitions

This table reports coefficients from panel regressions of operational losses on BHC M\&A activity and control variables. The estimation sample includes data for $159 \mathrm{M} \& \mathrm{~A}$ events from 38 large U.S. bank holding companies over the period [2001:Q1-2018:Q4]. LtA measures the operational losses that occur at a BHC over a given calendar quarter as a proportion of the BHC's total assets, multiplied by 1,000. Post $M \mathscr{E} A$ is an indicator variable that equals 1 after an M\&A event, and 0 otherwise. MEA Size (\%) is the asset size of an acquired company as a proportion of the BHC's asset size 1 quarter prior to the merger. The definitions of all variables are reported in Table 1 . We use observation windows of $+/-1,2,3$, or 4 quarters around each M\&A event. All specifications include M\&A event fixed effects. The error terms are clustered at the M\&A event level. $p$-values are presented in parentheses.

\begin{tabular}{lccccc}
\hline & $(1)$ & $(2)$ & $(3)$ & $(4)$ & $(5)$ \\
& LtA & LtA & LtA & LtA & LtA \\
\hline Post M\&A & $0.276^{* *}$ & $0.233^{* *}$ & $0.210^{* *}$ & $0.209^{* *}$ & $0.194^{* *}$ \\
& $(0.020)$ & $(0.022)$ & $(0.012)$ & $(0.012)$ & $(0.018)$ \\
Post M\&A * M\&A Size (\%) & & & & & $0.558^{*}$ \\
& & & & & $(0.100)$ \\
Ln(Assets) & $-1.497^{*}$ & -0.871 & -0.630 & $-0.641^{*}$ & $-0.951^{* *}$ \\
& $(0.074)$ & $(0.140)$ & $(0.116)$ & $(0.056)$ & $(0.029)$ \\
II-to-NII & $1.547^{* *}$ & $0.890^{*}$ & $0.953^{* *}$ & $0.875^{* * *}$ & $0.881^{* * *}$ \\
& $(0.010)$ & $(0.094)$ & $(0.011)$ & $(0.003)$ & $(0.003)$ \\
Deposits-to-Assets & 1.154 & 0.956 & -0.951 & -2.498 & $-2.855^{*}$ \\
& $(0.788)$ & $(0.728)$ & $(0.679)$ & $(0.140)$ & $(0.088)$ \\
Loans-to-Assets & -1.291 & 0.004 & 2.421 & $4.748^{* *}$ & $4.857^{* *}$ \\
& $(0.771)$ & $(0.999)$ & $(0.341)$ & $(0.040)$ & $(0.035)$ \\
ROE & 3.842 & -1.706 & -0.371 & 0.621 & 0.623 \\
& $(0.451)$ & $(0.493)$ & $(0.872)$ & $(0.774)$ & $(0.773)$ \\
Tier 1 Capital & 0.040 & 0.016 & 0.056 & $0.096^{* *}$ & $0.094^{* *}$ \\
& $(0.450)$ & $(0.699)$ & $(0.175)$ & $(0.032)$ & $(0.031)$ \\
Loan Losses & -16.309 & -11.824 & -28.725 & -34.934 & -34.947 \\
& $(0.632)$ & $(0.583)$ & $(0.188)$ & $(0.167)$ & $(0.168)$ \\
Maturity Gap & $1.020^{* * *}$ & $0.454^{*}$ & $0.342^{* *}$ & $0.188^{* *}$ & $0.211^{* *}$ \\
& $(0.004)$ & $(0.075)$ & $(0.022)$ & $(0.037)$ & $(0.028)$ \\
GDP Growth & $24.136^{*}$ & 9.796 & $9.506^{* *}$ & $9.025^{*}$ & $9.480^{* *}$ \\
& $(0.059)$ & $(0.229)$ & $(0.044)$ & $(0.051)$ & $(0.044)$ \\
Financial Crisis 2007-09 & 0.721 & 0.075 & 0.032 & 0.033 & 0.055 \\
& $(0.112)$ & $(0.866)$ & $(0.907)$ & $(0.883)$ & $(0.806)$ \\
\hline N Obs & 477 & 780 & 1071 & 1323 & 1323 \\
N M\&As & 159 & 156 & 153 & 147 & 147 \\
Adj $R^{2}$ & 0.37 & 0.25 & 0.34 & 0.31 & 0.31 \\
\hline$* 00.10{ }^{* *} p<0.05 F^{* * *} p<0.01$ & & & &
\end{tabular}


Table 9: Instrumental Variables

This table reports coefficients from instrumental variable regressions of operational losses on BHC asset growth and control variables. The estimation sample comprises an unbalanced panel of 1,644 quarterly observations of 38 large U.S. bank holding companies over the period [2001:Q12018:Q4]. LtA measures the operational losses that occur at a BHC over a given calendar quarter as a proportion of the bank's total assets, multiplied by 1,000. Asset Growth is the year-over-year growth of BHC total assets. We use $N$ Employees Growth, the year-over-year growth in the number of BHC employees, and Peer $N$ Employees Growth, the median year-over-year growth in the number of BHC employees of peer banks, as instrumental variables for Asset Growth. The definitions of all variables are reported in Table 1. Columns (1) and (2) present first stage results. Columns (3) and (4) present second stage results. Both regression stages include BHC fixed effects. Standard errors are clustered at the $\mathrm{BHC}$ and quarter levels. $p$-values are presented in parentheses.

\begin{tabular}{|c|c|c|c|c|}
\hline & \multicolumn{2}{|c|}{ First Stage } & \multicolumn{2}{|c|}{ Second Stage } \\
\hline & $(1)$ & $(2)$ & $(3)$ & $(4)$ \\
\hline & Asset Growth & Asset Growth & LtA & LtA \\
\hline N Employees Growth & $\begin{array}{l}0.816^{* * *} \\
(0.000)\end{array}$ & & & \\
\hline Peer N Employees Growth & & $\begin{array}{l}2.239^{* * *} \\
(0.000)\end{array}$ & & \\
\hline Asset Growth & & & $\begin{array}{l}0.380^{* * *} \\
(0.004)\end{array}$ & $\begin{array}{c}0.631^{* *} \\
(0.035)\end{array}$ \\
\hline Ln(Assets) & $\begin{array}{c}-0.020 \\
(0.162)\end{array}$ & $\begin{array}{c}0.006 \\
(0.808)\end{array}$ & $\begin{array}{c}-0.144^{* *} \\
(0.049)\end{array}$ & $\begin{array}{r}-0.148^{*} \\
(0.050)\end{array}$ \\
\hline II-to-NII & $\begin{array}{c}0.000 \\
(0.688)\end{array}$ & $\begin{array}{c}0.000 \\
(0.739)\end{array}$ & $\begin{array}{l}0.003^{* * *} \\
(0.007)\end{array}$ & $\begin{array}{l}0.002^{* * *} \\
(0.010)\end{array}$ \\
\hline Deposits-to-Assets & $\begin{array}{c}-0.205^{* * *} \\
(0.010)\end{array}$ & $\begin{array}{c}-0.022 \\
(0.821)\end{array}$ & $\begin{array}{c}0.088 \\
(0.791)\end{array}$ & $\begin{array}{c}0.123 \\
(0.728)\end{array}$ \\
\hline Loans-to-Assets & $\begin{array}{c}-0.161 \\
(0.213)\end{array}$ & $\begin{array}{c}-0.221 \\
(0.180)\end{array}$ & $\begin{array}{c}0.390 \\
(0.447)\end{array}$ & $\begin{array}{c}0.440 \\
(0.433)\end{array}$ \\
\hline $\mathrm{ROE}$ & $\begin{array}{c}0.042 \\
(0.340)\end{array}$ & $\begin{array}{c}0.205^{* *} \\
(0.029)\end{array}$ & $\begin{array}{c}0.645 \\
(0.254)\end{array}$ & $\begin{array}{c}0.554 \\
(0.314)\end{array}$ \\
\hline Tier 1 Capital & $\begin{array}{r}-0.009^{*} \\
(0.063)\end{array}$ & $\begin{array}{c}-0.015^{* *} \\
(0.028)\end{array}$ & $\begin{array}{c}-0.022 \\
(0.115)\end{array}$ & $\begin{array}{c}-0.016 \\
(0.177)\end{array}$ \\
\hline Loan Losses & $\begin{array}{c}-0.022 \\
(0.386)\end{array}$ & $\begin{array}{r}-0.042^{*} \\
(0.052)\end{array}$ & $\begin{array}{c}0.202 \\
(0.113)\end{array}$ & $\begin{array}{c}0.220^{*} \\
(0.076)\end{array}$ \\
\hline Maturity Gap & $\begin{array}{c}0.008 \\
(0.360)\end{array}$ & $\begin{array}{r}-0.007 \\
(0.571)\end{array}$ & $\begin{array}{r}-0.032 \\
(0.423)\end{array}$ & $\begin{array}{r}-0.030 \\
(0.467)\end{array}$ \\
\hline GDP Growth & $\begin{array}{c}0.183 \\
(0.672)\end{array}$ & $\begin{array}{r}-0.921^{*} \\
(0.082)\end{array}$ & $\begin{array}{c}1.288 \\
(0.599)\end{array}$ & $\begin{array}{l}1.400 \\
(0.585)\end{array}$ \\
\hline Financial Crisis 2007-09 & $\begin{array}{l}0.059^{* * *} \\
(0.003)\end{array}$ & $\begin{array}{c}0.057^{* *} \\
(0.012) \\
\end{array}$ & $\begin{array}{c}0.352 \\
(0.107) \\
\end{array}$ & $\begin{array}{c}0.331 \\
(0.110) \\
\end{array}$ \\
\hline N Obs & 1644 & 1644 & 1644 & 1644 \\
\hline $\operatorname{Adj} R^{2}$ & 0.68 & 0.50 & 0.03 & 0.03 \\
\hline
\end{tabular}

${ }^{*} p<0.10,{ }^{* *} p<0.05,{ }^{* * *} p<0.01$ 


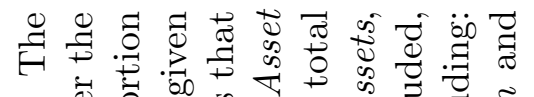

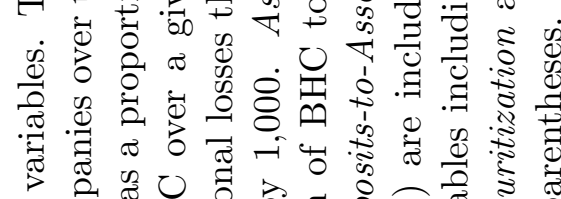

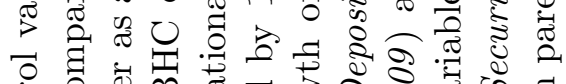

苞

仓

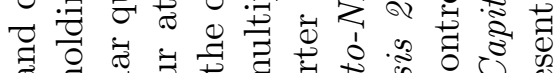

平隶

范

की

苋

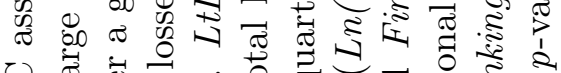

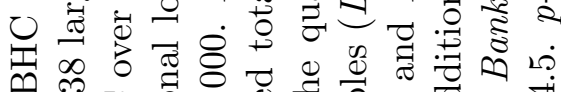

‡)

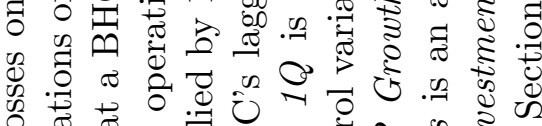

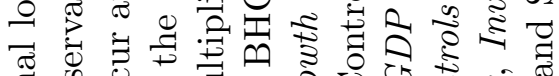

节 0 o

范范苛

०ै

प

य

.

की

के $\begin{gathered}0 \\ 0\end{gathered}$

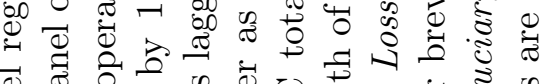

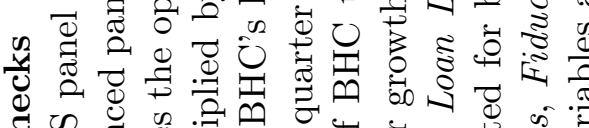

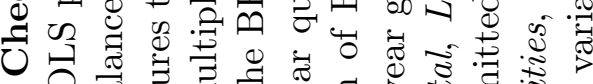

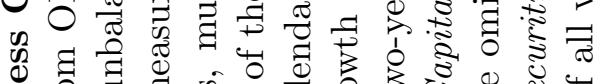

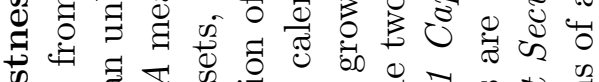

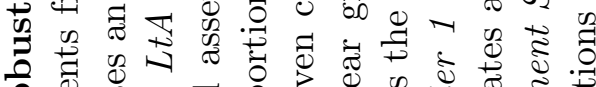

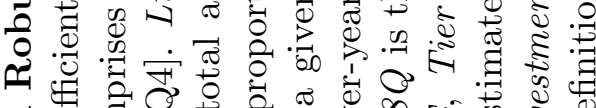
ส 0 द्व

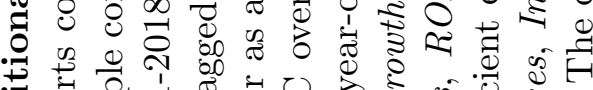

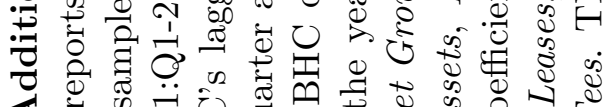

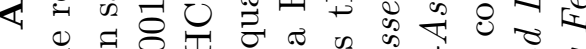

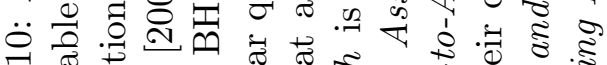

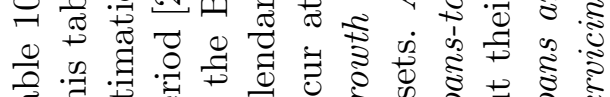
|

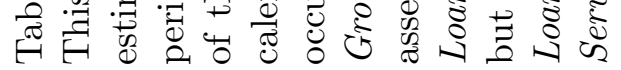


Table 11: Operational Losses and BHC Growth - Channels

This table reports coefficients from panel regressions of operational losses on BHC growth measures and control variables. The estimation sample comprises an unbalanced panel of: 1,018 quarterly observations of 26 large U.S. BHCs over the period [2001:Q1-2014:Q4] in Column (1); 1,048 quarterly observations of 25 large U.S. BHCs over the period [2004:Q1-2018:Q4] in Column (2); 1,644 quarterly observations of 38 large U.S. BHCs over the period [2001:Q1-2018:Q4] in Columns (3) and (4). LtA measures the operational losses that occur at a BHC over a given calendar quarter as a proportion of the BHC's total assets, multiplied by 1,000. Asset Growth is the year-over-year growth of BHC total assets. Execu Comp Vega is an indicator variable that equals 1 if vega (a compensation-based measure of executive risk-taking incentives) is greater than the sample median, 0 otherwise. Board Independence is an indicator variable that equals 1 if the proportion of independent directors on a BHC's board is greater than the sample median, 0 otherwise. $N$ Employees Growth is the year-over-year growth in the number of BHC employees. Asset Growth (Low Emp Growth), Asset Growth (Med Emp Growth) and Asset Growth (High Emp Growth) equal Asset Growth if $N$ Employees Growth is in the lowest, two inner, and highest quartiles, respectively, of $N$ Employees Growth's distribution, 0 otherwise. Control variables (Ln(Assets), II-to-NII, Depositsto-Assets, Loans-to-Assets, ROE, Tier 1 Capital, Loan Losses, Maturity Gap, GDP Growth and Financial Crisis 2007-09) are included, but their coefficient estimates are omitted for brevity. The definitions of all variables are reported in Table 1. All specifications include BHC fixed effects. The error terms are clustered at the BHC and quarter levels. $p$-values are presented in parentheses.

\begin{tabular}{|c|c|c|c|c|}
\hline & $\begin{array}{l}(1) \\
\text { LtA }\end{array}$ & $\begin{array}{c}(2) \\
\text { LtA }\end{array}$ & $\begin{array}{c}(3) \\
\text { LtA }\end{array}$ & $\begin{array}{l}(4) \\
\text { LtA }\end{array}$ \\
\hline Asset Growth & $\begin{array}{c}-0.115 \\
(0.417)\end{array}$ & $\begin{array}{c}0.959^{* *} \\
(0.047)\end{array}$ & & \\
\hline Asset Growth * Execu Comp Vega & $\begin{array}{c}0.680^{*} \\
(0.052)\end{array}$ & & & \\
\hline Execu Comp Vega & $\begin{array}{c}0.206 \\
(0.270)\end{array}$ & & & \\
\hline Asset Growth * Board Independence & & $\begin{array}{r}-0.810^{*} \\
(0.098)\end{array}$ & & \\
\hline Board Independence & & $\begin{array}{c}0.030 \\
(0.698)\end{array}$ & & \\
\hline N Employees Growth & & & $\begin{array}{l}0.310^{* * *} \\
(0.003)\end{array}$ & \\
\hline Asset Growth (Low Emp Growth) & & & & $\begin{array}{c}-0.071 \\
(0.842)\end{array}$ \\
\hline Asset Growth (Med Emp Growth) & & & & $\begin{array}{c}0.155 \\
(0.701)\end{array}$ \\
\hline Asset Growth (High Emp Growth) & & & & $\begin{array}{l}0.381^{* * *} \\
(0.007)\end{array}$ \\
\hline Controls & Yes & Yes & Yes & Yes \\
\hline N Obs & 1018 & 1048 & 1644 & 1644 \\
\hline $\operatorname{Adj} R^{2}$ & 0.06 & 0.08 & 0.06 & 0.06 \\
\hline
\end{tabular}

